\title{
Research progress on RNA-binding proteins in breast cancer (Review)
}

\author{
WENZHU ZHANG ${ }^{1,2^{*}}$, LINLIN LIU $^{3 *}$, SHENGDI ZHAO ${ }^{1,2}$, LIANG CHEN $^{1}$, \\ YUXIAN WEI ${ }^{4}$, WENLIN $\mathrm{CHEN}^{5}$ and FEI GE ${ }^{1}$ \\ ${ }^{1}$ Department of Breast Surgery, First Affiliated Hospital of Kunming Medical University, \\ Kunming, Yunnan 650032; ${ }^{2}$ No. 1 School of Clinical Medicine; ${ }^{3}$ School of Forensic Medicine, \\ Kunming Medical University, Kunming, Yunnan 650500; ${ }^{4}$ Department of Endocrine Breast Surgery, \\ First Affiliated Hospital of Chongqing Medical University, Chongqing 400016; ${ }^{5}$ Third Department of Breast Surgery, \\ The Third Affiliated Hospital of Kunming Medical University, Kunming, Yunnan 650118, P.R. China
}

Received November 20, 2021; Accepted February 3, 2022

DOI: $10.3892 / \mathrm{ol} .2022 .13241$

\begin{abstract}
Breast cancer is the most common malignancy among women, and the abnormal regulation of gene expression serves an important role in its occurrence and development. However, the molecular mechanisms underlying gene expression are highly complex and heterogeneous, and RNA-binding proteins (RBPs) are among the key regulatory factors. RBPs bind targets in an environment-dependent or environment-independent manner to influence mRNA stability and the translation of genes involved in the formation, progression, metastasis and treatment of breast cancer. Due to the growing interest in these regulators, the present review summarizes the most influential studies concerning RBPs associated with breast cancer to elucidate the role of RBPs in breast cancer and to assess how they interact with other key pathways to provide new molecular targets for the diagnosis and treatment of breast cancer.
\end{abstract}

\section{Contents}

1. Introduction

2. Eukaryotic translation initiation factor (eIF) $4 \mathrm{~A} 3$ and eIF4E

Correspondence to: Professor Fei Ge, Department of Breast Surgery, First Affiliated Hospital of Kunming Medical University, 295 Xichang Road, Kunming, Yunnan 650032, P.R. China

E-mail: ajqnadjd@hotmail.com

Professor Wenlin Chen, Third Department of Breast Surgery, The Third Affiliated Hospital of Kunming Medical University, 519 Kunzhou Road, Kunming, Yunnan 650118, P.R. China

E-mail: chenwenlin1@hotmail.com

${ }^{*}$ Contributed equally

Key words: breast cancer, RNA-binding protein, research progress
3. Hu-antigen $\mathrm{R}(\mathrm{HuR})$

4. IMPs

5. LIN28

6. Musashi (MSI)

7. RNA-binding motif protein 38 (RBM38)

8. SAM68

9. Conclusions

\section{Introduction}

Breast cancer is the most commonly reported type of cancer and the most common cause of cancer-associated mortality in women worldwide (1). Due to the high complexity and heterogeneity of breast tumors, the molecular mechanisms associated with their occurrence and development are still not fully understood (2). Breast cancer is categorized into the luminal A, luminal B, human epidermal growth factor receptor 2 (HER2)-positive and triple-negative breast cancer (TNBC) subtypes according to the expression status of the estrogen receptor (ER), progesterone receptor (PR) and HER2. Notably, $70 \%$ of breast tumors are ER-positive and rely on estrogen for growth (3). Endocrine therapy and selective ER modulators or aromatase inhibitors are the gold standards of treatment for $\mathrm{ER}^{+}$breast cancer; however, long-term endocrine therapy can cause the development of acquired resistance (4). HER2-positive breast cancer is mainly treated with targeted drugs, but there are inevitable side effects (5). TNBC is a subset of breast cancer characterized by the loss of ER, PR and HER2 expression. The TNBC subtype is defined by its high metastasis rate, fast tumor growth, early recurrence, low survival rate and lack of effective treatment $(6,7)$. Therefore, there is an urgent need to identify more molecules to serve as diagnostic and therapeutic targets for breast cancer.

Abnormal regulation of gene expression is the main cause of breast cancer development. With in-depth studies of the genetic and epigenetic mechanisms underlying breast cancer, increasing evidence has shown that gene expression in these cells is regulated in a number of ways (8-10). 
RNA-binding proteins (RBPs) are involved in various aspects of RNA metabolism, including RNA splicing, polyadenylation, sequence editing, RNA transport, maintenance of RNA stability and degradation, intracellular localization and translation control $(11,12)$. Any significant change or interference in the expression or activity of RBPs that regulate these basic cell functions can lead to different diseases, including cancer (13). RBPs are essential binding partners of intracellular RNA and engage in highly dynamic interactions with other proteins, coding RNAs and noncoding RNAs to form functional units called ribonucleoprotein complexes (RNPs); these complexes serve an important role in the regulation of post-transcriptional gene expression in a variety of ways. RBPs can rapidly and effectively alter gene expression, particularly in response to microenvironmental changes (14). It is clear that RBPs are abnormally regulated in breast cancer, thereby affecting the expression and function of oncoproteins and tumor suppressor proteins. Determining the intricate network of interactions between RBPs and breast cancer-related RNA targets will therefore contribute to a better understanding of tumor biology and potentially reveal new targets for cancer treatment. Based on these considerations, the present review aimed to critically discuss the role of RBPs in the occurrence, development and metastasis of breast cancer.

\section{Eukaryotic translation initiation factor (eIF)4A3 and eIF4E}

Translation initiation in eukaryotes is instigated by the binding of the eIF4F complex to the M7GTP cap structure of mRNA (15). The eIF4F complex contains the cap-binding protein eIF4E, the scaffold protein eIF4G and the ATP-dependent DEAD box RNA helicase eIF4A.

An isoform of eIF4A, eIF4A3, is the core component of the exon junction complex (16). eIF4A3 has been identified to serve an important role in post-transcriptional regulation, and is thought to be critical for mRNA splicing, transport, translation and monitoring $(17,18)$. eIF4A 3 has been reported to be overexpressed at the transcriptional level in common malignancies, and its overexpression in breast cancer is associated with shorter distant metastasis-free, and disease-free and overall survival (19). In addition, the knockdown of eIF4A3 has been shown to result in a defect in nonsense-mediated decay $(20,21)$, a quality control system that can degrade mRNA containing premature stop codons to prevent the accumulation of dysfunctional RNAs and proteins (22).

The Coexpedia database predicted the coexpression of genes related to eIF4A3 function (23). eIF4A3 was coexpressed with 312 genes, and the corresponding network revealed that eIF4A3 may regulate apoptosis and the cell cycle through a variety of tumor-related signaling pathways to promote tumor cell migration, invasion and drug resistance. The coexpression partners of eIF4A3 were closely related to the regulation of apoptosis, Wnt signaling, EGFR signaling, MAPK signaling and $\mathrm{TNF} / \mathrm{NF}-\kappa \mathrm{B}$ signaling (Table I) $(24,25)$.

There is growing evidence suggesting that eIF4E phosphorylation may be involved in numerous key processes in tumor biology, including cell proliferation, transformation, apoptosis, tumor metastasis and angiogenesis. A previous study reported that eIF4E is overexpressed and hyperphosphorylated in various subtypes of breast cancer; overexpression of eIF4E can lead to increased protein levels of cyclin D1, which is required for cells to enter $\mathrm{S}$ phase and is associated with cell proliferation (26) (Fig. 1). The activity of eIF4E is regulated by phosphorylation of two MAPK-interacting kinases (MNKs, i.e., MNK1 and MNK2) at a single residue (Ser209) $(27,28)$. Inhibition of MNKs can reduce cyclin D1 synthesis and inhibit the proliferation of breast cancer cells (29). Robichaud et al (30) reported that eIF4E $\mathrm{E}^{\mathrm{Ser} 209 \mathrm{~A}}$ mice, knock-in mice in which serine 209 was replaced by an alanine residue, were resistant to lung metastasis of breast cancer, and cells isolated from these mice had impaired invasion activities. The same group also revealed that in a mouse model of breast cancer, phosphorylation of eIF4E promoted neutrophil survival and accumulation, thereby promoting metastasis to the lung (31). Chrestensen et al (32) demonstrated that the levels of phosphorylated eIF4E were increased in HER2-overexpressing breast cancer cell lines, whereas inhibition of MNKs by the MNK inhibitor CGP 57380 reduced the proliferation of these cell lines. These studies point to the key role of MNKs in metastatic events. Notably, activation of the MNK signaling pathway downstream of EGFR/HER2 promotes XIAP expression and NF- $\kappa \mathrm{B}$ activity in inflammatory breast cancer (33). Taken together, these data suggest that eIF4E inhibition is a promising target for treating breast cancer.

\section{Hu-antigen R (HuR)}

HuR is a post-transcriptional regulator of RNA binding and a member of the $\mathrm{Hu} / \mathrm{ELAV}$ family (34). Clinical studies have shown that elevated HuR expression levels and cytoplasmic expression patterns are associated with breast malignancies (35). HuR expression levels have been revealed to be elevated in atypical ductal hyperplasia, ductal carcinoma in situ and ductal infiltrating carcinoma compared with the levels in healthy tissue (36-38). Cytoplasmic HuR expression has also been associated with malignancy, and binding of HuR to different target mRNAs can result in differential regulation of tumor-related processes. Notably, HuR has been shown to promote the growth of nontumorigenic MCF-10A cells and $\mathrm{ER}^{+} \mathrm{MCF}-7$ cells (39-41), but to have little effect on the growth of the highly tumorigenic ER-negative MDA-MB-231 cell line (42).

HuR recognizes and binds the U-rich sequence in the 3'-UTR of the target mRNA (43), which regulates mRNA stability and the translation of various genes involved in the formation, development, metastasis and treatment of breast cancer (44-47). HuR has been reported to regulate the mRNA expression levels of coding proteins involved in transcription [e.g.,GATA-3 (48,49), FOXO1 (50) and HOx-A5 $(51,52)$, cell signal transduction [e.g., Yes (53), WnT-5A (54), IGFIR (55) and ERBB2 (56)], cell cycle progression [e.g., p21 (57-59), p53 (60) and BRCA1 (61)], apoptosis [e.g., TNFSF12, CASP2 and BAX (62)], inflammation [e.g., IL-8 (63), COX-2 (64) and CSF-1-R (65)], adhesion and angiogenesis (e.g., CD9 (66), VEGF-A (67), THBS1 (67) and MMP-9 (68)] (Fig. 2; Table I). These processes are associated with cancer and malignant transformation. In addition, the direct effect of $\mathrm{HuR}$ on the translation efficiency may be positive or negative. Overall, HuR has been demonstrated to bind 38 protein-coding mRNAs in breast cell lines to post-transcriptionally regulate 
Table I. Summary of the cellular functions of RBPs in BC.

\begin{tabular}{|c|c|c|c|c|}
\hline $\mathrm{RBP}$ & Expression in $\mathrm{BC}$ & Functions & Pathways/targets & (Refs.) \\
\hline eIF4A3 & Upregulation & $\begin{array}{l}\text { Promotes migration, } \\
\text { invasion and } \\
\text { chemoresistance; } \\
\text { inhibits apoptosis; regulates } \\
\text { the cell cycle }\end{array}$ & $\begin{array}{l}\text { Wnt, EGFR, MAPK and } \\
\text { TNF/NF- } \kappa \text { B signaling pathways }\end{array}$ & $(24,25)$ \\
\hline eIF4E & Upregulation & $\begin{array}{l}\text { Promotes proliferation, } \\
\text { migration and angiogenesis; } \\
\text { inhibits apoptosis }\end{array}$ & Cyclin D1 & $(26-33)$ \\
\hline HuR & Upregulation & $\begin{array}{l}\text { Promotes inflammation } \\
\text { and apoptosis; inhibits } \\
\text { adhesion and angiogenesis; } \\
\text { regulates the cell cycle }\end{array}$ & $\begin{array}{l}\text { GATA-3, FOXO1, HOx-A5, Yes, } \\
\text { Wnt-5A, IGFIR, ERBB2, p21, } \\
\text { p53, BRCA1, TNFSF12, CASP2, } \\
\text { BAX, IL-8, COX-2, CSF-1-R, } \\
\text { CD9, VEGF-A, THBS1, MMP-9 } \\
\text { and } \triangle \text { Np63 }\end{array}$ & $(34-71)$ \\
\hline \multicolumn{5}{|l|}{ IMPs } \\
\hline IMP1 & Downregulation & $\begin{array}{l}\text { Inhibits proliferation, } \\
\text { migration and invasion }\end{array}$ & $\begin{array}{l}\text { E-cadherin, } \beta \text {-actin, } \alpha \text {-actinin, } \\
\text { Arp } 2 / 3, \text { RGS } 4, \text { GDF15, IGF2, } \\
\text { PTG } 2 \text { and } \beta \text {-catenin }\end{array}$ & $(86-91)$ \\
\hline IMP2 & Upregulation & $\begin{array}{l}\text { Upregulates the autoimmune } \\
\text { response, proliferation and } \\
\text { migration }\end{array}$ & $\mathrm{PR}$ & $(92-94)$ \\
\hline IMP3 & Upregulation & $\begin{array}{l}\text { Promotes migration, } \\
\text { invasion, stemness and } \\
\text { chemoresistance }\end{array}$ & $\begin{array}{l}\text { CD164, MMP-9, SLUG, Wnt5B, } \\
\text { BCRP and PR }\end{array}$ & $(95-98,101,105)$ \\
\hline LIN28 & Upregulation & $\begin{array}{l}\text { Promotes proliferation, } \\
\text { migration, stemness, } \\
\text { radioresistance and } \\
\text { chemoresistance; } \\
\text { regulates the cell cycle }\end{array}$ & $\begin{array}{l}\text { MYC, HMGA2 and PI3K-mTOR } \\
\text { pathways; cyclin D1/D2, } \\
\text { CDC25A, CDK34, CDK6, RKIP, } \\
\text { RAD51, RAD21, FANCD2, } \\
\text { CDC25, P-gp, let-7, Rb, p21 and } \\
\text { Bcl-XL }\end{array}$ & $(113-127)$ \\
\hline MSI & Upregulation & $\begin{array}{l}\text { Promotes proliferation, } \\
\text { chemoresistance and } \\
\text { stemness; regulates the } \\
\text { cell cycle; inhibits apoptosis, } \\
\text { migration and invasion }\end{array}$ & $\begin{array}{l}\text { p21 }{ }^{\text {Cip1 }}, \text { Wnt } 4, \beta \text {-catenin and } \\
\text { Notch signaling pathways; } \\
\text { ERBB2 (MSI-1); ER } \alpha(\text { MSI-2); } \\
\text { CD44, GBX2, Vimentin, EGFR, } \\
\text { DNA-PKCS and LIFR }\end{array}$ & $\begin{array}{c}(129,132,133,136,137, \\
148-150)\end{array}$ \\
\hline RBM38 & Downregulation & $\begin{array}{l}\text { Inhibits proliferation, } \\
\text { migration, invasion, the } \\
\text { EMT and; chemoresistance } \\
\text { induces cell arrest in } \\
\text { the } \mathrm{G}_{1} \text { phase }\end{array}$ & $\begin{array}{l}\text { p21, C-Myc, p63, MDM2, p53, } \\
\text { PR, Era, PTEN, ZO-1, Mutp53 } \\
\text { and STARD13-correlated ceRNA } \\
\text { network }\end{array}$ & $(158,161-163,168-171)$ \\
\hline SAM68 & Upregulation & $\begin{array}{l}\text { Promotes proliferation, } \\
\text { migration and invasion }\end{array}$ & $\begin{array}{l}\text { Bcl-XL, CD44, SGCE, } \\
\text { cardiophilin, cyclin D1, Src, } \\
\text { BRK, P59fyn, PI3K, PRMT, } \\
\text { FBP21, FBP309, PRMT1, p21 } \\
\text { and p27 }\end{array}$ & $\begin{array}{c}(172,173,176-181 \\
186,190,191,194)\end{array}$ \\
\hline
\end{tabular}

BC, breast cancer; RBP, RNA-binding protein.

their expression (69). In most cases, HuR stabilized the target mRNA, but the CD9 antigen mRNA levels were markedly downregulated in MDA-MB-231 HuR-overexpressing cells and upregulated in cells with small interfering RNA 


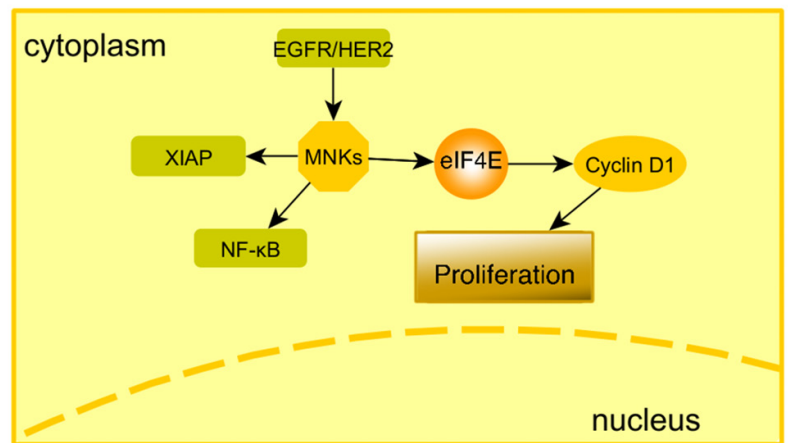

Figure 1. eIF4E, its target genes and its modulators in cellular pathways. Arrows indicate activation.

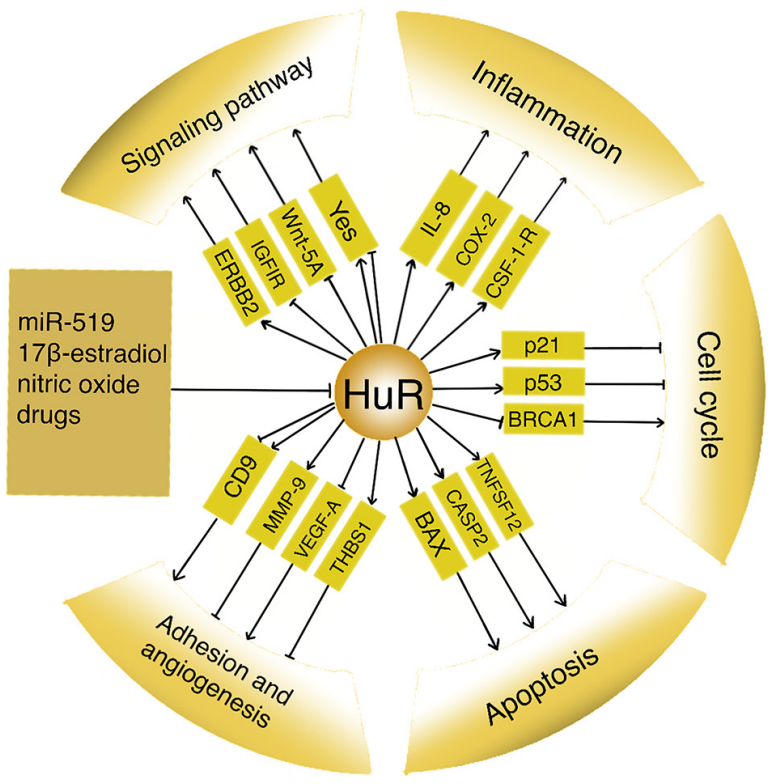

Figure 2. HuR, its target genes and its modulators in cellular pathways Arrows indicate activation and blunted lines indicate inhibition.

(siRNA)-mediated HuR silencing (66). HuR is also thought to influence translation as evidenced by its inhibition of Wnt-5A (70), $\Delta \mathrm{Np} 63$ (71), IGF-1-R (55) and BRCA1 (61) protein production.

Exon-intron splicing and polyadenylation of mRNA occurring in the nucleus can also be modulated by HuR (41,71-73). Moreover, HuR can be transported along with bound mRNAs from the nucleus to the cytoplasm (74), and this change in subcellular localization appears to be related to the regulation of HuR function (75). In turn, HuR mRNA and protein expression levels are affected by some proteins and microRNAs (miRNAs/miRs), such as miR-519 (76); hormones, such as $17 \beta$-estradiol (77); cyclic GMP-elevating agents, such as nitric oxide (78); and drugs.

The aforementioned findings indicated that HuR may be a promising drug target for the treatment of breast cancer. Several chemicals, such as dehydromutactin (79), MS-444 (79), okicenone (79), quercetin (40), b-40 (40), b-41 (40), mitoxanthrone (80), CMLD-2 (81) and 15,16-dihydrotanshinone (82), have been reported to bind $\mathrm{HuR}$ and disrupt the interaction among HuR dimers, HuR and mRNA. However, more research is required to fully understand its potential as a drug target and determine which subtypes of breast cancer and at which stages of the disease HuR-targeting drugs would be most effective.

\section{IMPs}

IMPs, also known as insulin-like growth factor 2 (IGF2) mRNA-binding proteins, are highly conserved oncofetal RBPs. Three mammalian IMP paralogs (IMP1-3) are expressed in the majority of organs during embryogenesis, and are considered to serve an essential role in cell migration, metabolism and stem cell renewal. These three homologous genes regain their physiological function in malignant cells and are expressed in a wide range of cancer types, where their expression is often associated with poor prognosis (83-85).

IMP1 has been shown to be commonly expressed in normal adult breast epithelial cells, as well as in mouse and human breast tumor cells (86). Activation of IMP1 may help maintain cell polarity and directional movement by regulating the localization of E-cadherin, $\beta$-actin, $\alpha$-actinin and Arp $2 / 3$ complex mRNA; this inhibits chemotaxis and metastasis of breast cancer cells (87-89) (Fig. 3; Table I). In addition, IMP1 expression may upregulate RGS4 mRNA, and downregulate GDF15, IGF2 and PTG2 mRNA, inhibiting tumor cell proliferation and invasion (90). IMP1 expression is regulated by the Wnt pathway, and $\beta$-catenin has been shown to bind the IMP1 promoter and activate the gene (91). IMP1 has also been observed to stabilize $\beta$-catenin mRNA, suggesting that a positive feedback loop exists between $\beta$-catenin and IMP1 in which they regulate the expression of each other (91). High levels of (promoter methylation and significant downregulation of IMP1 expression have been observed in all metastatic breast cancer cell lines, including MTLn3, MDA-MB-435, MDA-MB-231 and 4T1, but promoter methylation and downregulation of IMP1 expression were only slight in nonmetastatic cell lines, including MTC and T47D cells $(87,88)$. It can be concluded from these in vitro and in vivo studies that IMP1 methylation events may become more frequent with increased breast cancer grade, which leads to more IMP1 silencing and downregulation events, resulting in dysregulated effects on IMP1-targeted mRNAs. Notably, IMP1 lacking the KH3/4 domain has been shown to have no RNA-binding activity, thus resulting in the loss of inhibitory function against tumor progression (90).

Compared with the luminal or apocrine subtypes, basal breast cancer tissues show overexpression of IMP2 (92). Liu et al (93) further reported that IMP2 was overexpressed in breast cancer tissue and upregulated the autoimmune response. In mice with fusiform and squamous differentiated breast cancer, CCN6/WISP3 knockdown could upregulate IMP2 expression (94). Furthermore, CCN6 secreted from normal mammary epithelium can inhibit the protein expression of IMP2 in breast cancer tissue, thereby regulating tumor growth (94). Thus, it may be inferred that the overexpression of IMP2 is not only a potential biomarker of the occurrence of breast cancer but may also considered a new diagnostic factor.

IMP3 is preferentially expressed in TNBC (95) and is associated with the function of breast cancer stem cells (CSCs) (96). Upon induction by the EGFR signaling-activated mitogen-activated protein kinase pathway in these tumors, 


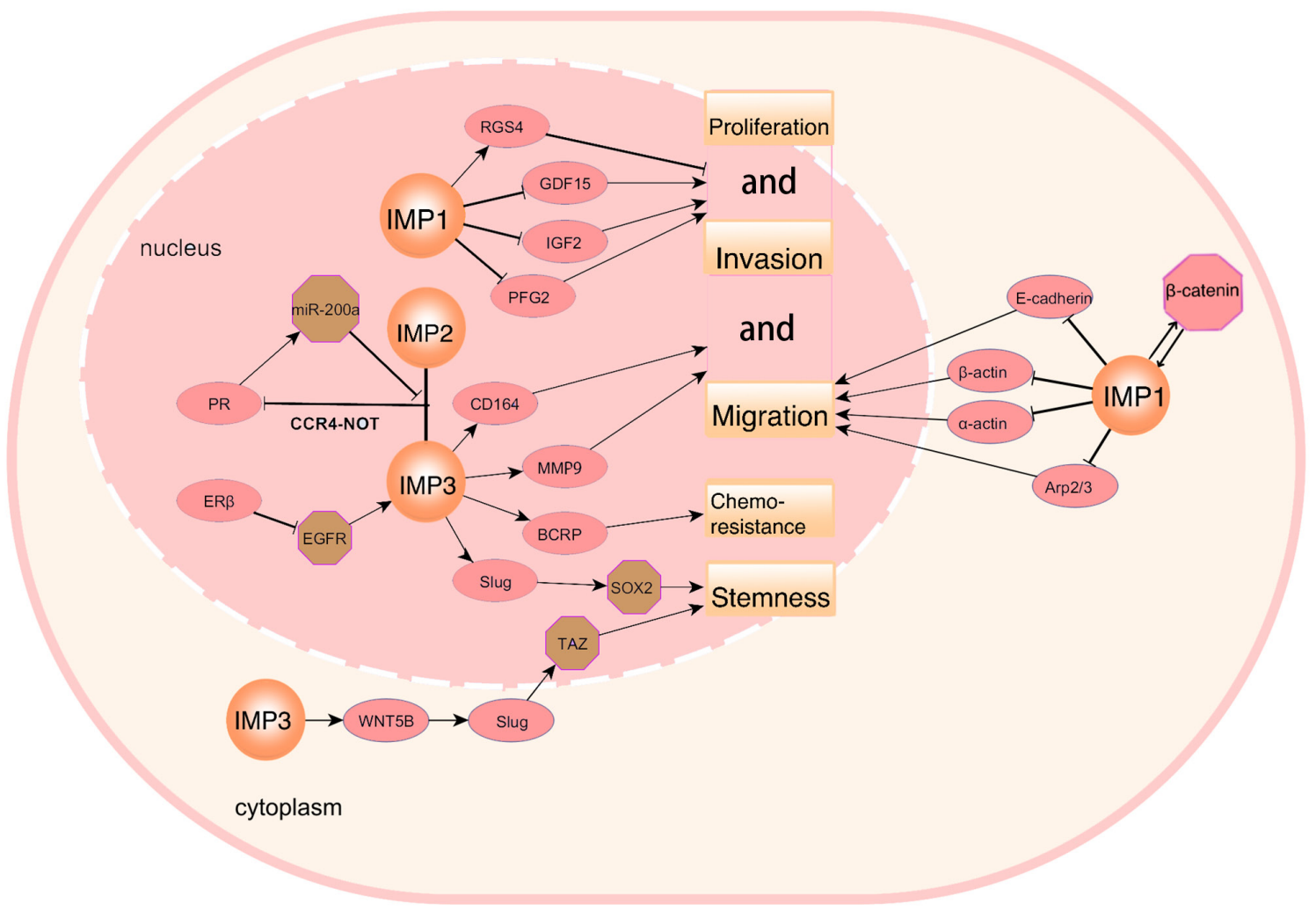

Figure 3. IMPs, their target genes and their modulators in cellular pathways. Arrows indicate activation and blunted lines indicate inhibition.

IMP3 expression is inhibited by $3 \beta$ a-diol, the ligand of $\operatorname{ER} \beta$ (97). Experiments performed in cell lines suggest that $\mathrm{ER} \beta$ indirectly inhibits IMP3 based on the discovery that ER $\beta$ inhibits EGFR transcription (97). Moreover, IMP3 has been reported to bind several key mRNAs that may promote migration and invasion, including CD164 and MMP-9 (97) (Fig. 3; Table I). IMP3 has been shown to promote stem-like properties in TNBC via the stem cell factor SOX2, the transcriptional target of SLUG; in addition, IMP3 may mediate the post-transcriptional regulation of SLUG (98). SLUG, a member of the SNAIL family of transcriptional repressors, is preferentially expressed in TNBC and is involved in the occurrence of these tumors $(99,100)$. Furthermore, IMP3 can indirectly stabilize WNT ligand (WNT5B) mRNA by targeting the miR145-5P binding site on WNT5B mRNA, resulting in TAZ activation by alternative WNT signaling. IMP3 and WNT5B also work together to promote SLUG transcription, which is required for the nuclear localization and activation of TAZ (101). TAZ is preferentially expressed in TNBC, which is of great significance for breast CSCs and poorly differentiated tumors (102). Breast cancer resistance protein (BCRP), also known as ABCG2, is a member of the ATP-binding cassette transporter family and is a major effector of drug resistance in breast cancer (103). It has been shown that doxorubicin and mitoxantrone, two chemotherapeutic drugs used in the treatment of breast cancer, are effluxed from cells by BCRP (104). IMP3 may promote chemotherapy resistance by binding BCRP mRNA and regulating its expression (105).

It has been demonstrated that miR-200a directly suppresses IMP2/3 expression by targeting the 3'-UTR. By contrast, IMP2 and IMP3 may suppress the transcription of miR-200a via recruitment of the CCR4-NOT transcription complex subunit 1 complex to destabilize PR mRNA. Therefore, the identified IMP2/3-miR-200a-PR axis double-negative feedback loop may serve as a novel potential therapeutic target for TNBC (106) (Fig. 3; Table I).

\section{LIN28}

LIN28 has been identified as an RBP involved in breast cancer proliferation, metastasis, drug resistance and stem cell renewal. LIN28 has two RNA-binding motifs: A cold shock domain and a Cys-Cys-His-Cys zinc finger domain (107). Mammals produce two similar LIN28 isoforms: LIN28A and LIN28B, which share the same primary structure and function but differ in more subtle ways (108). For example, LIN28B has nuclear localization signals (NLSs) and a nucleolar localization signal, and is mainly localized to the nucleus and nucleoli; however, LIN28A is mainly located in the cytoplasm. The key functions of LIN28 fall into two classifications: Let-7-dependent and let-7-independent. miRNAs of the let-7 family are key inhibitory targets of LIN28 and serve as effective tumor suppressors via post-transcriptional inhibition of a variety of oncogenic mRNAs (109). Previous studies have indicated that LIN28 is transcriptionally activated by upstream factors, such as C-Myc, $\mathrm{NF}-\kappa \mathrm{B}$, Src and Wnt $(110,111)$.

Breast cancer cells are characterized by a hypoxic microenvironment and extracellular acidosis. During carbonic anhydrase IX (CAIX)-mediated adaptation to hypoxia and acidosis in carcinogenesis, CAIX increases the LIN28 protein levels, followed by pyruvate dehydrogenase kinase 1 upregulation and enhanced glycolysis. CAIX is a hypoxia-induced 


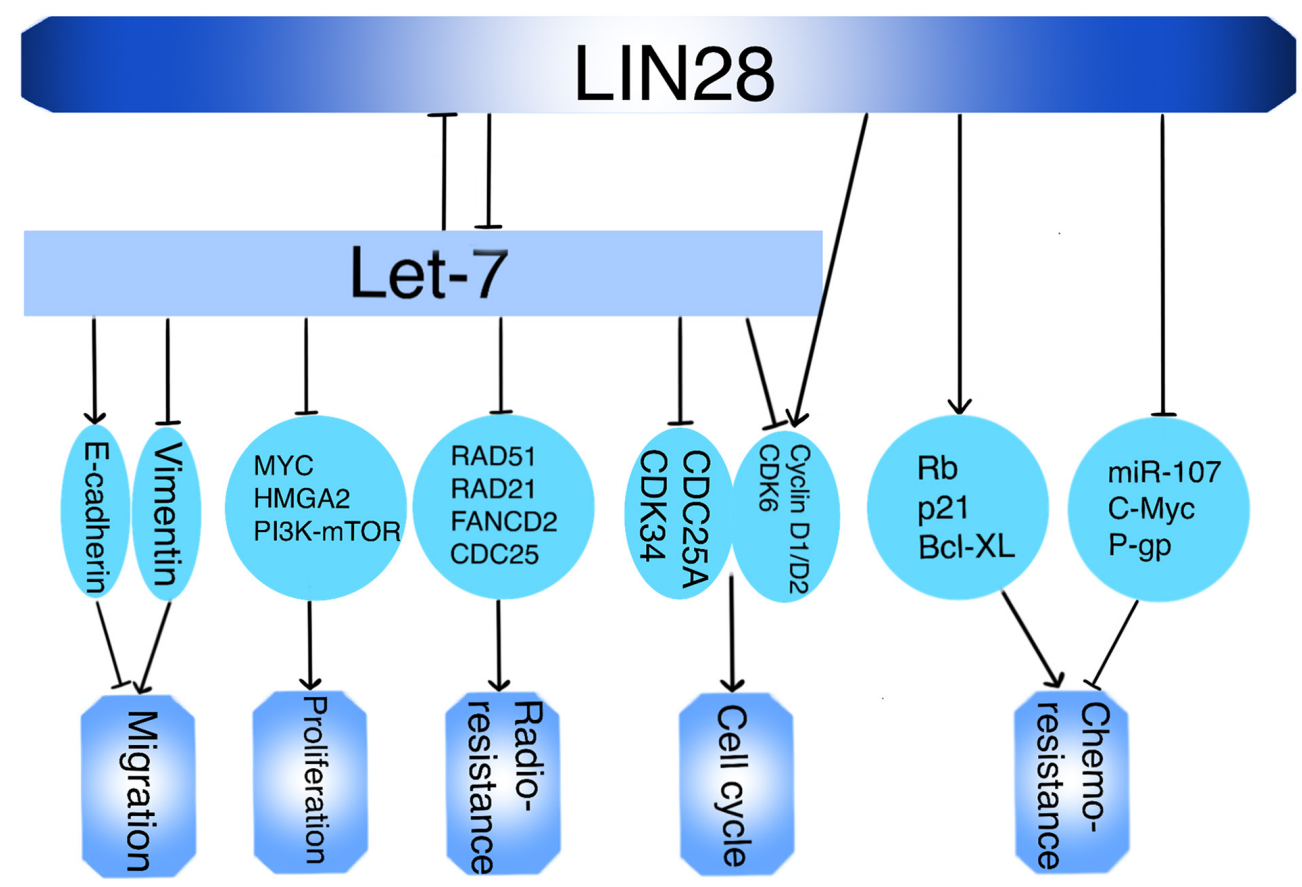

Figure 4. LIN28, its target genes and its modulators in cellular pathways. Arrows indicate activation and blunted lines indicate inhibition.

pH regulator that modulates LIN28/Let-7 axis-mediated metabolic metastasis and stemness in breast cancer cells (112). Arguably, the most fundamental feature of LIN28 in breast cancer cells is its ability to promote proliferation. Numerous studies on tumor proliferation have shown that LIN28 acts as an oncogene by inhibiting let-7, resulting in the dysregulation of multiple genes directly or indirectly regulated by let-7, including components of MYC (such as C-Myc, N-Myc and L-Myc), HMGA2 and PI3K-mTOR pathways (113-116) (Fig. 4). In terms of the cell cycle, LIN28 may promote the proliferation of tumor cells by inhibiting let-7 and increasing the expression of cyclin-related factors, such as cyclin D1/D2, CDC25A, CDK34 and CDK6 (117) (Table I). In addition, the LIN28/let-7 axis has been reported to be involved in preventing angiogenesis in breast cancer. Isanejad et al (118) reported that the expression of aggressive breast cancer cell markers (such as Ki67 and $\mathrm{ER} \alpha$ ) or tumor vascular markers (such as HIF-1 $\alpha$, CD31 and VEGF) could be downregulated through the let-7a pathway when combined with hormone therapy.

LIN28 may also contribute to bone metastasis of breast tumors expressing Raf kinase inhibitory protein (119). The overexpression of LIN28 in breast cancer cells has been reported to significantly reduce the expression of E-cadherin and increase the expression of vimentin, thus promoting metastasis (120). Furthermore, let-7a can inhibit cell migration in breast cancer cell lines by significantly blocking the direct binding target of LIN28 (121). Low expression of LIN28 and overexpression of let-7 can increase the radiosensitivity of cancer cells by reducing the expression of RAS oncogenes and DNA-related genes, such as RAD51, RAD21, FANCD2 and CDC25 (122-124). In terms of drug resistance, the overexpression of LIN28 has been demonstrated to reduce the sensitivity of cells to chemotherapy by inhibiting miR-107 expression, as well as the RNA and protein expression levels of C-Myc and P-gp (125). Other investigators have reported that LIN28-induced chemotherapy resistance is associated with let-7, $\mathrm{Rb}, \mathrm{p} 21$ and $\mathrm{Bcl}-\mathrm{XL}$, thus clarifying the complex relationship between LIN28 and tumor drug resistance $(126,127)$. These findings provide evidence for the potential therapeutic effect of a strategy targeting LIN28 against breast cancer metastasis.

\section{Musashi (MSI)}

MSI is an evolutionarily conserved RBP, which modifies translation by binding to $(\mathrm{G} / \mathrm{A}) \mathrm{U}_{1-3}(\mathrm{AGU})$ motifs in the 3'-UTR of its target mRNAs (128). Two different proteins have been identified: MSI-1 and MSI-2. MSI-1 is associated with a variety of tumor types, and its function is essential for tumor growth in breast cancer, colon cancer, medulloblastoma and glioblastoma. MSI-1 regulates apoptosis, differentiation, proliferation and cell cycle progression by mediating different post-transcriptional processes (129-131). In addition, MSI-1 may be a target gene of the Wnt pathway; the target protein p21 (Cip1) negatively regulates Wnt 4 and $\beta$-catenin, through which MSI- 1 expression can be automatically regulated $(132,133)$. This finding is consistent with MSI-1 activating Notch and Wnt activity, and the nuclear localization of $\beta$-catenin in mammary epithelial cells (134). In addition, the overexpression of C-Myc has been reported to result in a significant increase in MSI-1 protein and mRNA expression (135). MSI-1 was shown to be strongly correlated with the Notch pathway, and to serve an important role in stem cell self-renewal and cell fate determination $(136,137)$. Notch is activated by the sequential proteolytic cleavage of its membrane-associated form to a constitutively active intracellular form [Notch intracellular domain (NIC)], which serves as a transcription coactivator (138). The maintenance of NIC is affected by the negative regulator Numb, which ubiquitinates and targets NIC for proteasomal destruction $(139,140)$, and its expression is inhibited by MSI-1 (139) (Fig. 5). The NIC and Notch ligands Jagged and Delta have been shown to be highly 


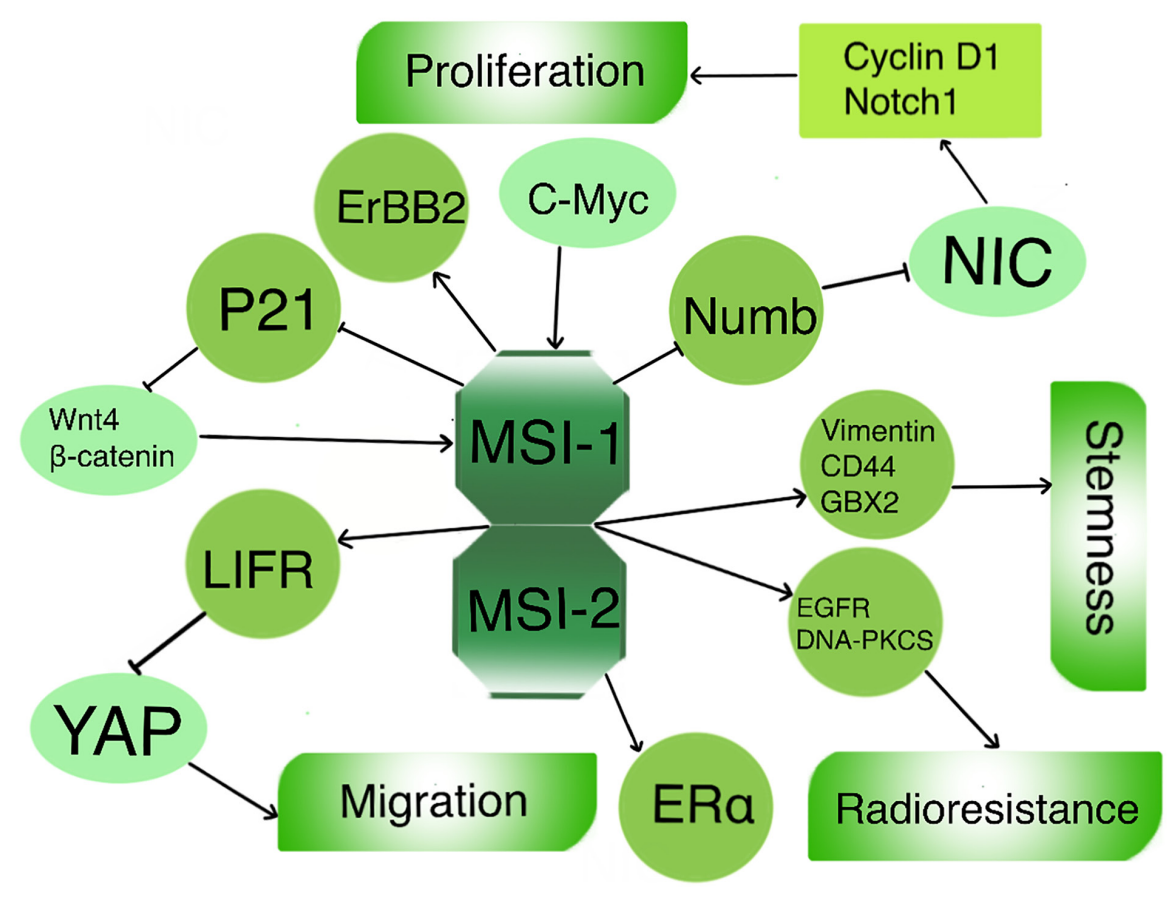

Figure 5. MSI, their target genes and their modulators in cellular pathways. Arrows indicate activation and blunted lines indicate inhibition.

expressed in breast cancer $(141,142)$, and it has been reported that $50 \%$ of high-grade human breast cancer cases exhibit a loss of Numb expression, which is negatively correlated with the tumor grade (143). Furthermore, MSI-1 has been shown to be highly expressed in $40 \%$ of primary breast tumors and $100 \%$ of lymph node-positive tumors and corresponds to a poor prognosis for survival (129). In breast cancer cell lines, MSI-1 expression is also associated with HER2 activity (129), and HER2-induced cell proliferation and cyclin D1 expression depend on Notch activation and Numb inhibition (136). Therefore, these findings suggested that MSI-1 may have an important role in mediating the progression of HER2-positive breast cancer.

MSI-2 has been identified as a novel ubiquitination target protein of deleted in breast cancer 2 (DBC2) (137). DBC2, also known as Rho-related BTB domain-containing protein 2, is classified as a tumor suppressor gene (144-146) that functions as a substrate-specific adaptor protein for a novel class of Cullin-3-based E3 ubiquitin ligases (147). MSI-2 interacts directly with DBC2, and this interaction promotes MSI-2 polyubiquitination and proteasomal degradation in breast cancer cells (137). This provides evidence that $\mathrm{DBC} 2$ may inhibit the occurrence of breast cancer via MSI-2 ubiquitination. In $\mathrm{ER}^{+}$ breast cancer, MSI-2 expression is highly enriched, and MSI-2 expression is significantly correlated with estrogen receptor 1 (ESR1) expression (Fig. 5; Table I). Furthermore, MSI-2 can increase the stability of the ESR 1 protein by binding to the 3'-UTR of ESR1 mRNA (148). In summary, MSI-2 may act as the upstream regulator of ESR1, thus having clinical significance in $\mathrm{ER}^{+}$breast cancer.

Previous studies have shown that both MSI-1 and MSI-2 are highly expressed in TNBC $(128,149)$. In breast cancer, the expression levels of CD44, GBX2 and the mesenchymal protein vimentin have been shown to be downregulated upon MSI knockdown (150); these three proteins are key stem cell markers of breast malignant tumors (151-153). This strongly points to the effect of MSI on proliferation and potential apoptosis. Furthermore, MSI protein knockdown can reduce radiotherapy resistance in breast cancer by downregulating EGFR and DNA-PKCS expression (150). However, MSI protein knockdown can lead to higher cell invasiveness and increased migration in vivo, possibly due to downregulation of the LIF receptor (LIFR) (150). In breast cancer, LIFR is referred to as a metastasis inhibitor and is upstream of the Hippo-YAP pathway: high LIFR expression has been reported to inhibit metastasis by inactivating the transcription coactivator YAP through a cascade of polyphosphorylation processes (154). In summary, these data suggested that targeting MSI has potential therapeutic value; however, since metastasis is a key determinant of overall survival, increased cell migration and invasion are clear and troubling consequences of MSI silencing. Further offsetting the invasive and migratory nature of MSI silencing is critical before determining its therapeutic value in breast cancer.

\section{RNA-binding motif protein 38 (RBM38)}

RBM38, also known as RNPC1, belongs to the RRM family of RBPs, and may affect the proliferation, cell cycle arrest and epithelial-mesenchymal transition (EMT) of cancer cells (155-157). In 2014, to the best of our knowledge, Xue et al (156) reported for the first time that RBM38 was downregulated at the mRNA and protein expression levels in multiple breast cancer cell lines, as well as in 121 pairs of human breast cancer and adjacent normal tissues. RBM38 is expressed as two isoforms: RBM38a and RBM38b. In vitro, RBM38a overexpression has been reported to inhibit the proliferation, migration and invasion of $\mathrm{ER}^{+} \mathrm{MCF}-7$ and triple-negative MDA-MB-231 cells by arresting cells in $\mathrm{G}_{1}$ phase (156). In a clinical sense, RBM38 has been shown to be positively correlated with long-term relapse-free and overall survival (158). 


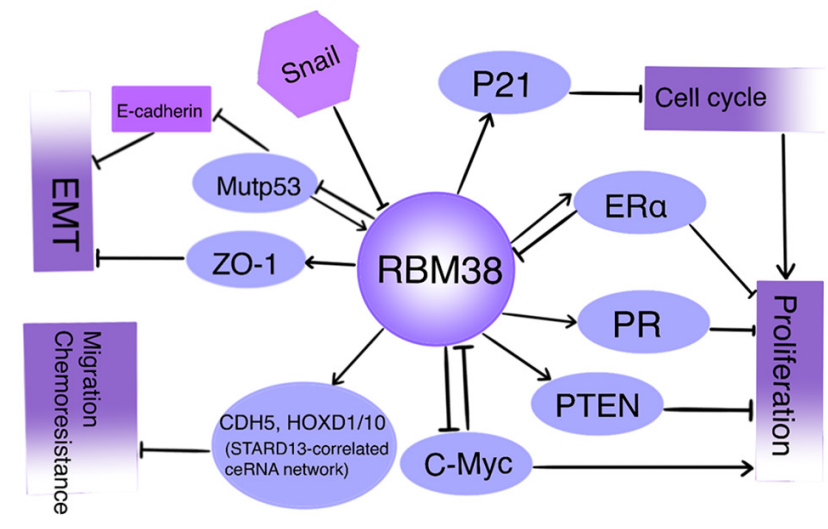

Figure 6. RBM38, its target genes and its modulators in cellular pathways. Arrows indicate activation and blunted lines indicate inhibition.

RBM38 has been shown to induce $\mathrm{G}_{1}$-phase arrest by binding and stabilizing p21 transcripts (159) (Fig. 6; Table I), and its expression may be negatively correlated with C-Myc at the protein level (160). C-Myc is a well-known oncogene that is overexpressed in numerous types of human cancer and promotes $G_{1} / S$ cell cycle progression (161). Although $\mathrm{C}-\mathrm{Myc}$ is generally considered a transcriptional activator, it binds the E-box region of the RBM38 promoter to inhibit its transcription, which, in turn, results in the destabilization of C-Myc mRNA in $\mathrm{ER}^{+}$breast cancer cells (160). RBM38 also has negative effects when regulating the transcription of its target (such as binding the mRNAs of P63, MDM2 and p53), mediating the instability of its mRNAs and attenuating their translation. In addition, RBM38A protein expression has been shown to be significantly positively correlated with that of ER $\alpha$ (162) and PR (163). RBM38 can stabilize the mRNA expression levels of PR and $\operatorname{ER} \alpha$, but not $E R \beta$, in $\mathrm{ER}^{+} / \mathrm{PR}^{+}$breast cancer cells. However, $\mathrm{ER} \alpha$ has been reported to negatively regulate RBM38 expression in response to estrogen stimulation (162). RBM38 may serve a role in tumor suppression by partially enhancing PTEN expression. PTEN, a well-characterized tumor suppressor, is an inhibitor of the PI3K/Akt pathway, which is frequently overactivated in several types of cancer and is associated with metastasis and CSCs (164-167). RBM38 can positively affect the expression and activity of PTEN in breast cancer cells by acting on the PTEN 3'-UTR (168).

EMT alters the polarity of epithelial cells and stem cell properties, thus contributing to metastasis and drug resistance (169). Notably, during TGF- $\beta$-induced EMT in $\mathrm{ER}^{+}$breast cancer cells, RBM38 expression is lost via Snail-mediated transcriptional suppression through the E-box element in the RBM38 promoter (170). Biologically, RBM38 blocks the EMT by upregulating the mRNA stability of the epithelial marker ZO-1 (170). In addition, RBM38 overexpression has been shown to decrease the expression of Mutp53 protein in breast cancer. Mutp53 could induce partial EMT-like transitions as reflected in the increased suppression of E-cadherin synthesis (171); thus, Mutp53 may be involved in the RBM38-regulated EMT process. Notably, RBM38 may promote competing endogenous RNA (ceRNA) interactions among STARD13, CDH5, HOXD10 and HOXD1 (STARD13-correlated ceRNA network) in breast cancer

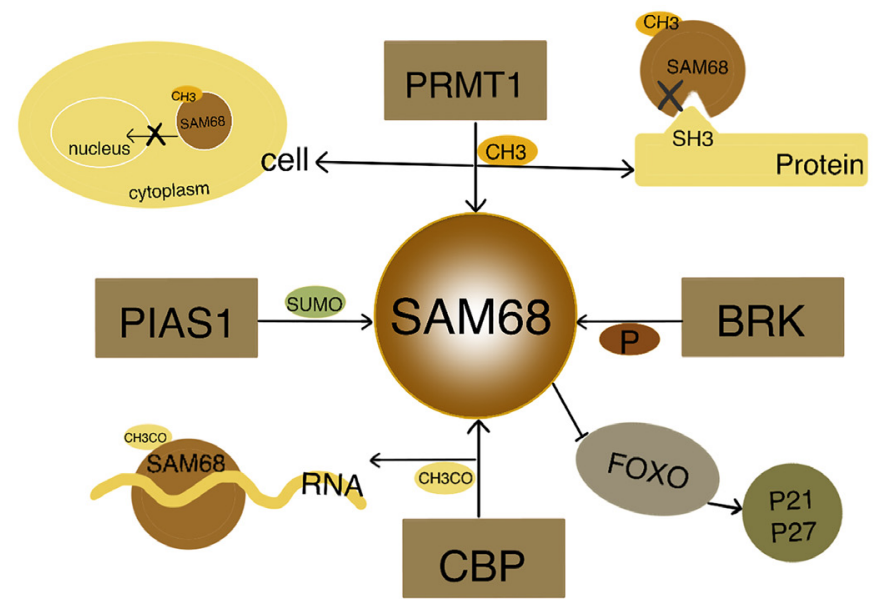

Figure 7. SAM68, its target genes and its modulators in cellular pathways. Arrows indicate activation and blunted or crossed-out lines indicate inhibition.

tissues; by promoting the expression of these four genes in breast cancer cells, breast cancer cell metastasis is inhibited and Adriamycin resistance is attenuated (158).

In summary, the genomic characterization and expression pattern of RBM38 provide evidence for its tumor-suppressive effect in breast cancer and highlight the diversity of its mechanisms in different biological contexts. These data also suggest the potential value of RBM38 with respect to future targeted tumor therapies.

\section{SAM68}

SAM68 was originally identified as a substrate for Src-associated in mitosis and is a member of the signal transduction and RNA activation family $(172,173)$. SAM68 is considered to be an RBP that links extracellular signal transduction and RNA processing $(174,175)$, and has an hnRNP K homologous domain, which is required for binding to RNA with high specificity and high affinity. It has been reported that SAM68 can nonspecifically interact with the poly(U) and poly(A) chains of RNA molecules, and can also specifically interact with UAAA or UUUA structures (174). Selective splicing of multiple genes, such as Bcl-XL, CD44, SGCE, cardiophilin and cyclin D1, has been shown to be regulated by SAM68 $(176,177)$ (Table I). In addition, SAM68 has been reported to interact with numerous signaling proteins, such as Src, BRK, P59fyn, PI3K, PRMT, FBP21 and FBP309, through their SRC homologous $(\mathrm{SH}) 2, \mathrm{SH} 3$ and WW domains, suggesting that SAM68 may also be involved in various biological processes as an adaptor protein for signal transduction (172,173,178-181).

SAM68 contains six proline-rich sequences and a tyrosine-rich region at the $\mathrm{C}$-terminus, which form docking sites for signaling proteins containing SH2 and SH3 domains (180-183). Notably, the tyrosine phosphorylation of Src-associated kinases has been reported to impair SAM68 homodimerization (173), and its RNA affinity in vitro $(181,184)$ and in vivo $(185)$. Other post-translational modifications have also been reported to affect the function of this RBP. SAM68 binds and is methylated by the arginine methyltransferase PRMT1 (186), thus 
influencing SAM68 and SH3 domain interactions (187) and its nuclear localization (186) (Fig. 7). Furthermore, SAM68 acetylation by the acetyltransferase CBP in oncogenic breast cancer cell lines (188) has been shown to increase the binding of SAM68 to RNA. In addition, SAM68 can be sumoylated by the SUMO E3 ligase PIAS1, thereby enhancing its transcriptional inhibitory activity (189). Thus, post-translational modifications greatly influence the biochemical properties of SAM68 and fine-tune its subcellular localization, interactions with signaling proteins, and RNA binding affinity.

The tyrosine phosphorylation of SAM68 may also affect its role in breast cancer cells. The breast tumor kinase BRK is an overexpressed nonreceptor tyrosine kinase in human breast cancer cells (190), which can promote proliferation and anchorage-independent growth (191). SAM68 was identified as one of the first substrates of BRK, and its phosphorylated tyrosine residue overlaps with the NLS of SAM68. BRK-dependent phosphorylation has been reported to induce transient subcellular relocation of SAM68 in cells stimulated with EGF to induce proliferation (192). Because tyrosine phosphorylation reduces the RNA-binding activity of SAM68 while enhancing its interaction with signaling proteins (193), it is likely that BRK activation leads to functional reprogramming of SAM68 activity in breast cancer cells. Notably, SAM68 and BRK have been reported to be upregulated in breast cancer, supporting their role in cell proliferation and invasion $(190,191,194)$.

SAM68 can also promote polarization movements and cell migration independent of its RNA-binding activity (195). The positive role of SAM68 in tumor transformation has been demonstrated in other types of human cancer (196-198). It has been demonstrated that SAM68-deficient cells exhibit intron 5 retention in mTOR mRNA, resulting in an early termination codon and a reduction in the mTOR protein levels (199). Notably, mTOR is a key effector in the cellular signaling pathway of human cancer, and the overexpression of related components in the PI3K/AKT/mTOR pathway has been demonstrated to induce malignant transformation (200). Notably, the loss of SAM68 can reduce the incidence of breast cancer, suggesting that SAM68 activation may also regulate the expression of PI3K downstream mTOR in breast cancer cells (201). SAM68 deficiency in breast cancer cells may also impair cell proliferation and tumorigenic properties by upregulating the expression of the cyclin-dependent kinase inhibitors p21 (Cip1) and p27 (Kip1). Thus, in this case, the loss of SAM68 may lead to reductions in Akt phosphorylation and the subsequent activation of the FOXO factor, thereby promoting the expression of p21 and p27 (194). This finding is consistent with the role of SAM68 in breast tumorigenesis in vivo. SAM68-knockout mice have been reported to be insensitive to tumor formation in vivo (202), and SAM68 haploid insufficiency can delay the onset of breast tumors and reduces the spread of metastases (201). These results suggested that high levels of SAM68 are necessary for cell transformation in vivo and support the role of SAM68 as a proto-oncogene. In addition, in patients with breast cancer, the expression and cytoplasmic localization of SAM68 have been shown to be significantly correlated with their clinical characteristics, including clinical stage, tumor-node-metastasis grade, histological grade and ER expression status (194). Thus, SAM68 may be considered an attractive target for breast cancer treatment; however, a better understanding of its functions in breast cancer cells is required to develop tools to interfere with its activity.

\section{Conclusions}

Numerous studies have shown that disruptions in RBPs occur in different subtypes of breast cancer and affect every step of breast cancer development. RBPs regulate gene expression to induce or reduce the expression levels of genes associated with breast cancer. As described in this review, some RBPs have been found to regulate multiple genes involved in breast cancer development simultaneously, leading to different changes in cancer progression. With the development of research techniques, such as single-cell analysis, and cross-linking and immunoprecipitation, several new RBPs and their partners have been discovered. However, in general, the complex regulatory network of RBPs is still not fully understood, as much remains to be discovered with respect to the role of RBPs in breast cancer biology.

Based on the results of previous studies, researchers have attempted to target RBPs and/or their partners in clinical and nonclinical studies using siRNA, antisense-oligonucleotides and small molecules. However, for most of the RBPs described in the present review, no drugs are currently being tested, let alone clinically available. More research should be conducted to expand the understanding of RBP interaction networks and to develop specific ways to target RBPs in cancer therapy without affecting adjacent normal cells.

In conclusion, the present review highlights the regulatory role of RBPs in the occurrence and progression of breast cancer. Considering the number of RBPs whose functions are still not completely understood, current knowledge about breast cancer-related RBPs is in its infancy, thus reinforcing the need for future studies.

\section{Acknowledgements}

Not applicable.

\section{Funding}

The present study was supported by the National Natural Science Foundation of China (grant nos. 82060543 and 82060538) and the Yunnan Fundamental Research Projects (grant no. 202101AT070347).

\section{Availability of data and materials}

Not applicable.

\section{Authors' contributions}

WZ and LL searched the literature and wrote the manuscript. SZ, LC and YW searched the literature. FG and WC conceived the idea for the review, critically revised the manuscript and provided the final approval. All authors read and approved the final manuscript. Data authentication is not applicable.

\section{Ethics approval and consent to participate}

Not applicable. 


\section{Patient consent for publication}

Not applicable.

\section{Competing interests}

The authors declare that they have no competing interests.

\section{References}

1. Smith RA, Andrews KS, Brooks D, Fedewa SA, ManassaramBaptiste D, Saslow D and Wender RC: Cancer screening in the United States, 2019: A review of current American cancer society guidelines and current issues in cancer screening. CA Cancer J Clin 69: 184-210, 2019.

2. Skibinski A and Kuperwasser C: The origin of breast tumor heterogeneity. Oncogene 34: 5309-5316, 2015.

3. Wang L, Gallo KA and Conrad SE: Targeting mixed lineage kinases in ER-positive breast cancer cells leads to G2/M cell cycle arrest and apoptosis. Oncotarget 4: 1158-1171, 2013.

4. Sommer S and Fuqua SA: Estrogen receptor and breast cancer Semin Cancer Biol 11: 339-352, 2001.

5. Slamon D, Leyland-Jones B, Shak S, Fuchs H, Paton V, Bajamonde A, Fleming T, Eiermann W, Wolter J, Pegram M, et al: Use of chemotherapy plus a monoclonal antibody against HER2 for metastatic breast cancer that overexpresses HER2. N Engl J Med 344: 783-792, 2001.

6. Foulkes WD, Smith IE and Reis-Filho JS: Triple-negative breast cancer. N Engl J Med 363: 1938-1948, 2010.

7. Montagna E, Maisonneuve P, Rotmensz N, Cancello G, Iorfida M Balduzzi A, Galimberti V, Veronesi P, Luini A, Pruneri G, et al: Heterogeneity of triple-negative breast cancer: Histologic subtyping to inform the outcome. Clin Breast Cancer 13: 31-39, 2013.

8. Zuo T, Wang L, Morrison C, Chang X, Zhang H, Li W, Liu Y, Wang Y, Liu X, Chan MWY, et al: FOXP3 is an X-linked breast cancer suppressor gene and an important repressor of the HER-2/ErbB2 oncogene. Cell 184: 6378, 2021.

9. Yamamoto S, Wu Z, Russnes HG, Takagi S, Peluffo G, Vaske C Zhao X, Moen Vollan HK, Maruyama R, Ekram MB, et al: JARID1B is a luminal lineage-driving oncogene in breast cancer. Cancer Cell 25: 762-777, 2014.

10. Li Z, Tognon CE, Godinho FJ, Yasaitis L, Hock $\mathrm{H}$, Herschkowitz JI, Lannon CL, Cho E, Kim SJ, Bronson RT, et al: ETV6-NTRK3 fusion oncogene initiates breast cancer from committed mammary progenitors via activation of AP1 complex. Cancer Cell 12: 542-558, 2007.

11. Dreyfuss G, Kim VN and Kataoka N: Messenger-RNA-binding proteins and the messages they carry. Nat Rev Mol Cell Biol 3: 195-205, 2002.

12. Mitchell SF and Parker R: Principles and properties of eukaryotic mRNPs. Mol Cell 54: 547-558, 2014

13. Wang ZJ, Li B, Luo YX, Lin Q, Liu SR, Zhang XQ, Zhou H, Yang JH and Qu LH: Comprehensive genomic characterization of RNA-binding proteins across human cancers. Cell Rep 22 286-298, 2018

14. Smith CW and Valcárcel J: Alternative pre-mRNA splicing: The logic of combinatorial control. Trends Biochem Sci 25: 381-388, 2000.

15. Marcotrigiano J, Gingras AC, Sonenberg N and Burley SK Cocrystal structure of the messenger RNA 5' cap-binding protein (eIF4E) bound to 7-methyl-GDP. Cell 89: 951-961, 1997.

16. Saulière J, Murigneux V, Wang Z, Marquenet E, Barbosa I, Le Tonquèze $\mathrm{O}$, Audic $\mathrm{Y}$, Paillard $\mathrm{L}$, Roest Crollius $\mathrm{H}$ and Le Hir H: CLIP-seq of eIF4AIII reveals transcriptome-wide mapping of the human exon junction complex. Nat Struct Mol Biol 19: 1124-1131, 2012 .

17. Gehring NH, Lamprinaki S, Kulozik AE and Hentze MW: Disassembly of exon junction complexes by PYM. Cell 137: 536-548, 2009.

18. Ali MAM: DEAD-box RNA helicases: The driving forces behind RNA metabolism at the crossroad of viral replication and antiviral innate immunity. Virus Res 296: 198352, 2021.

19. Mizuno H, Kitada K, Nakai K and Sarai A: PrognoScan: A new database for meta-analysis of the prognostic value of genes. BMC Med Genomics 2: 18, 2009
20. Palacios IM, Gatfield D, St Johnston D and Izaurralde E: An eIF4AIII-containing complex required for mRNA localization and nonsense-mediated mRNA decay. Nature 427: 753-757, 2004.

21. Shibuya T, Tange TØ, Sonenberg N and Moore MJ: eIF4AIII binds spliced mRNA in the exon junction complex and is essential for nonsense-mediated decay. Nat Struct Mol Biol 11: 346-351, 2004

22. Ito M, Tanaka T, Cary DR, Iwatani-Yoshihara M, Kamada Y, Kawamoto T, Aparicio S, Nakanishi A and Imaeda Y: Discovery of novel 1,4-diacylpiperazines as selective and cell-active eIF4A3 inhibitors. J Med Chem 60: 3335-3351, 2017.

23. Lin Y, Zhang J, Cai J, Liang R, Chen G, Qin G, Han X, Yuan C, Liu Z, Li Y, et al: Systematic analysis of gene expression alteration and co-expression network of eukaryotic initiation factor 4A-3 in cancer. J Cancer 9: 4568-4577, 2018.

24. Nusse $\mathrm{R}$ and Clevers $\mathrm{H}$ : Wnt/ $/ \beta$-catenin signaling, disease, and emerging therapeutic modalities. Cell 169: 985-999, 2017.

25. Mitchell JP and Carmody RJ: NF- $\kappa \mathrm{B}$ and the transcriptional control of inflammation. Int Rev Cell Mol Biol 335: 41-84, 2018.

26. Baldin V, Lukas J, Marcote MJ, Pagano M and Draetta G: Cyclin $\mathrm{D} 1$ is a nuclear protein required for cell cycle progression in G1. Genes Dev 7: 812-821, 1993.

27. Waskiewicz AJ, Johnson JC, Penn B, Mahalingam M, Kimball SR and Cooper JA: Phosphorylation of the cap-binding protein eukaryotic translation initiation factor $4 \mathrm{E}$ by protein kinase Mnk1 in vivo. Mol Cell Biol 19: 1871-1880, 1999.

28. Fukunaga R and Hunter T: MNK1, a new MAP kinase-activated protein kinase, isolated by a novel expression screening method for identifying protein kinase substrates. EMBO J 16: 1921-1933, 1997.

29. Wheater MJ, Johnson PW and Blaydes JP: The role of MNK proteins and eIF4E phosphorylation in breast cancer cell proliferation and survival. Cancer Biol Ther 10: 728-735, 2010.

30. Robichaud N, del Rincon SV, Huor B, Alain T, Petruccelli LA, Hearnden J, Goncalves C, Grotegut S, Spruck CH, Furic L, et al: Phosphorylation of eIF4E promotes EMT and metastasis via translational control of SNAIL and MMP-3. Oncogene 34: 2032-2042, 2015.

31. Robichaud N, Hsu BE, Istomine R, Alvarez F, Blagih J, Ma EH, Morales SV, Dai DL, Li G, Souleimanova M, et al: Translational control in the tumor microenvironment promotes lung metastasis: Phosphorylation of eIF4E in neutrophils. Proc Natl Acad Sci USA 115: E2202-E2209, 2018.

32. Chrestensen CA, Shuman JK, Eschenroeder A, Worthington M, Gram $\mathrm{H}$ and Sturgill TW: MNK1 and MNK2 regulation in HER2-overexpressing breast cancer lines. J Biol Chem 282: 4243-4252, 2007

33. Evans MK, Brown MA, Geradts J, Bao X, Robinson TJ, Jolly MK, Vermeulen PB, Palmer GM, Gromeier M, Levine H, et al: XIAP regulation by MNK links MAPK and NFKB signaling to determine an aggressive breast cancer phenotype. Cancer Res 78: 1726-1738, 2018

34. Ma WJ, Cheng S, Campbell C, Wright A and Furneaux $\mathrm{H}$ : Cloning and characterization of HuR, a ubiquitously expressed Elav-like protein. J Biol Chem 271: 8144-8151, 1996

35. Kotta-Loizou I, Giaginis C and Theocharis S: Clinical significance of HuR expression in human malignancy. Med Oncol 31: 161,2014

36. Ortega AD, Sala S, Espinosa E, González-Barón M and Cuezva JM: HuR and the bioenergetic signature of breast cancer: A low tumor expression of the RNA-binding protein predicts a higher risk of disease recurrence. Carcinogenesis 29: 2053-2061, 2008.

37. Xu F, Zhang X, Lei Y, Liu X, Liu Z, Tong T and Wang W: Loss of repression of HuR translation by miR-16 may be responsible for the elevation of HuR in human breast carcinoma. J Cell Biochem 111: 727-734, 2010.

38. Heinonen M, Hemmes A, Salmenkivi K, Abdelmohsen K, Vilén ST, Laakso M, Leidenius M, Salo T, Hautaniemi S, Gorospe M, et al: Role of RNA binding protein HuR in ductal carcinoma in situ of the breast. J Pathol 224: 529-539, 2011.

39. Stylianou S, Clarke RB and Brennan K: Aberrant activation of notch signaling in human breast cancer. Cancer Res 66: $1517-1525,2006$

40. Chae MJ, Sung HY, Kim EH, Lee M, Kwak H, Chae CH, Kim S and Park WY: Chemical inhibitors destabilize HuR binding to the AU-rich element of TNF-alpha mRNA. Exp Mol Med 41: 824-831, 2009.

41. Izquierdo $\mathrm{JM}: \mathrm{Hu}$ antigen $\mathrm{R}(\mathrm{HuR})$ functions as an alternative pre-mRNA splicing regulator of Fas apoptosis-promoting receptor on exon definition. J Biol Chem 283: 19077-19084, 2008. 
42. Al-Ahmadi W, Al-Ghamdi M, Al-Souhibani N and Khabar KS miR-29a inhibition normalizes HuR over-expression and aberrant AU-rich mRNA stability in invasive cancer. J Pathol 230: 28-38, 2013.

43. López de Silanes I, Zhan M, Lal A, Yang X and Gorospe M: Identification of a target RNA motif for RNA-binding protein HuR. Proc Natl Acad Sci USA 101: 2987-2992, 2004.

44. Brennan CM and Steitz JA: HuR and mRNA stability. Cell Mol Life Sci 58: 266-277, 2001.

45. Myer VE, Fan XC and Steitz JA: Identification of HuR as a protein implicated in AUUUA-mediated mRNA decay. EMBO J 16: 2130-2139, 1997.

46. Fan XC and Steitz JA: Overexpression of HuR, a nuclearcytoplasmic shuttling protein, increases the in vivo stability of ARE-containing mRNAs. EMBO J 17: 3448-3460, 1998.

47. Peng SS, Chen CY, Xu N and Shyu AB: RNA stabilization by the AU-rich element binding protein, HuR, an ELAV protein. EMBO J 17: 3461-3470, 1998.

48. Hoch RV, Thompson DA, Baker RJ and Weigel RJ: GATA-3 is expressed in association with estrogen receptor in breast cancer. Int J Cancer 84: 122-128, 1999.

49. Licata LA, Hostetter CL, Crismale J, Sheth A and Keen JC: The RNA-binding protein HuR regulates GATA3 mRNA stability in human breast cancer cell lines. Breast Cancer Res Treat 122 55-63, 2010.

50. Li Y, Yu J, Du D, Fu S, Chen Y, Yu F and Gao P: Involvement of post-transcriptional regulation of FOXO1 by HuR in 5-FU-induced apoptosis in breast cancer cells. Oncol Lett 6: 156-160, 2013.

51. Yang F, Miao L, Mei Y and Wu M: Retinoic acid-induced HOXA5 expression is co-regulated by HuR and miR-130a. Cell Signal 25: 1476-1485, 2013.

52. Rhoads K, Arderiu G, Charboneau A, Hansen SL, Hoffman W and Boudreau N: A role for Hox A5 in regulating angiogenesis and vascular patterning. Lymphat Res Biol 3: 240-252, 2005.

53. Sommer S, Cui Y, Brewer G and Fuqua SA: The c-Yes 3'-UTR contains adenine/uridine-rich elements that bind AUF1 and HuR involved in mRNA decay in breast cancer cells. J Steroid Biochem Mol Biol 97: 219-229, 2005.

54. Leris AC, Roberts TR, Jiang WG, Newbold RF and Mokbel K WNT5A expression in human breast cancer. Anticancer Res 25 731-734, 2005

55. Meng Z, Jackson NL, Choi H, King PH, Emanuel PD and Blume SW: Alterations in RNA-binding activities of IRES-regulatory proteins as a mechanism for physiological variability and pathological dysregulation of IGF-IR translational control in human breast tumor cells. J Cell Physiol 217: 172-183, 2008

56. Scott GK, Marx C, Berger CE, Saunders LR, Verdin E, Schäfer S, Jung $M$ and Benz CC: Destabilization of ERBB2 transcripts by targeting 3' untranslated region messenger RNA associated HuR and histone deacetylase-6. Mol Cancer Res 6: 1250-1258, 2008.

57. Wang W, Furneaux H, Cheng H, Caldwell MC, Hutter D, Liu Y, Holbrook N and Gorospe M: HuR regulates p21 mRNA stabilization by UV light. Mol Cell Biol 20: 760-769, 2000.

58. Yan W, Zhang Y,Zhang J, Cho SJ and Chen X: HuR is necessary for mammary epithelial cell proliferation and polarity at least in part via $\Delta$ Np63. PLoS One 7: e45336, 2012.

59. Giles KM, Daly JM, Beveridge DJ, Thomson AM, Voon DC, Furneaux HM, Jazayeri JA and Leedman PJ: The 3'-untranslated region of p21WAF1 mRNA is a composite cis-acting sequence bound by RNA-binding proteins from breast cancer cells, including HuR and poly(C)-binding protein. J Biol Chem 278 : 2937-2946, 2003.

60. Chock K, Allison JM and Elshamy WM: BRCA1-IRIS overexpression abrogates UV-induced p38MAPK/p53 and promotes proliferation of damaged cells. Oncogene 29: 5274-5285, 2010

61. Saunus JM, French JD, Edwards SL, Beveridge DJ, Hatchell EC Wagner SA, Stein SR, Davidson A, Simpson KJ, Francis GD, et al: Posttranscriptional regulation of the breast cancer susceptibility gene BRCA1 by the RNA binding protein HuR. Cancer Res 68 : 9469-9478, 2008.

62. Mazan-Mamczarz K, Hagner PR, Dai B, Wood WH, Zhang Y, Becker KG, Liu Z and Gartenhaus RB: Identification of transformation-related pathways in a breast epithelial cell model using a ribonomics approach. Cancer Res 68: 7730-7735, 2008

63. Suswam ES, Nabors LB, Huang Y, Yang X and King PH: IL-1beta induces stabilization of IL-8 mRNA in malignant breast cancer cells via the 3' untranslated region: Involvement of divergent RNA-binding factors HuR, KSRP and TIAR. Int J Cancer 113: 911-919, 2005 .
64. Hsia TC, Tu CY, Chen YJ, Wei YL, Yu MC, Hsu SC, Tsai SL, Chen WS, Yeh MH, Yen CJ, et al: Lapatinib-mediated cyclooxygenase-2 expression via epidermal growth factor receptor/HuR interaction enhances the aggressiveness of triple-negative breast cancer cells. Mol Pharmacol 83: 857-869, 2013.

65. Woo HH, Zhou Y, Yi X, David CL, Zheng W, Gilmore-Hebert M, Kluger HM, Ulukus EC, Baker T, Stoffer JB and Chambers SK: Regulation of non-AU-rich element containing c-fms protooncogene expression by HuR in breast cancer. Oncogene 28 1176-1186, 2009

66. Calaluce R, Gubin MM, Davis JW, Magee JD, Chen J, Kuwano Y, Gorospe M and Atasoy U: The RNA binding protein HuR differentially regulates unique subsets of mRNAs in estrogen receptor negative and estrogen receptor positive breast cancer. BMC Cancer 10: 126, 2010.

67. Gubin MM, Calaluce R, Davis JW, Magee JD, Strouse CS, Shaw DP, Ma L, Brown A, Hoffman T, Rold TL and Atasoy U: Overexpression of the RNA binding protein HuR impairs tumor growth in triple negative breast cancer associated with deficient angiogenesis. Cell Cycle 9: 3337-3346, 2010.

68. Yuan Z, Sanders A, Ye L, Wang Y and Jiang WG: Prognostic value of the human antigen $\mathrm{R}(\mathrm{HuR})$ in human breast cancer: High level predicts a favourable prognosis. Anticancer Res 31: 303-310, 2011.

69. Kotta-Loizou I, Vasilopoulos SN, Coutts RH and Theocharis S Current evidence and future perspectives on $\mathrm{HuR}$ and breast cancer development, prognosis, and treatment. Neoplasia 18: 674-688, 2016

70. Leandersson K, Riesbeck K and Andersson T: Wnt-5a mRNA translation is suppressed by the Elav-like protein HuR in human breast epithelial cells. Nucleic Acids Res 34: 3988-3999, 2006.

71. Zhu H, Zhou HL, Hasman RA and Lou H: Hu proteins regulate polyadenylation by blocking sites containing U-rich sequences. J Biol Chem 282: 2203-2210, 2007.

72. Mukherjee N, Corcoran DL, Nusbaum JD, Reid DW, Georgiev S, Hafner M, Ascano M Jr, Tuschl T, Ohler U and Keene JD: Integrative regulatory mapping indicates that the RNA-binding protein HuR couples pre-mRNA processing and mRNA stability. Mol Cell 43: 327-339, 2011

73. Akaike Y, Masuda K, Kuwano Y, Nishida K, Kajita K, Kurokawa K, Satake Y, Shoda K, Imoto I and Rokutan K: HuR regulates alternative splicing of the TRA2 $\beta$ gene in human colon cancer cells under oxidative stress. Mol Cell Biol 34: 2857-2873, 2014.

74. Fan XC and Steitz JA: HNS, a nuclear-cytoplasmic shuttling sequence in HuR. Proc Natl Acad Sci USA 95: 15293-15298, 1998

75. Keene JD: Why is $\mathrm{Hu}$ where? Shuttling of early-response-gene messenger RNA subsets. Proc Natl Acad Sci USA 96: 5-7, 1999.

76. Abdelmohsen K, Srikantan S, Kuwano Y and Gorospe M: miR-519 reduces cell proliferation by lowering RNA-binding protein HuR levels. Proc Natl Acad Sci USA 105: 20297-20302, 2008.

77. Cabilla JP, Nudler SI, Ronchetti SA, Quinteros FA, Lasaga M and Duvilanski BH: Nitric oxide-sensitive guanylyl cyclase is differentially regulated by nuclear and non-nuclear estrogen pathways in anterior pituitary gland. PLoS One 6: e29402, 2011.

78. Akool ES, Kleinert H, Hamada FM, Abdelwahab MH, Förstermann U, Pfeilschifter J and Eberhardt W: Nitric oxide increases the decay of matrix metalloproteinase 9 mRNA by inhibiting the expression of mRNA-stabilizing factor HuR. Mol Cell Biol 23: 4901-4916, 2003.

79. Meisner NC, Hintersteiner M, Mueller K, Bauer R, Seifert JM, Naegeli HU, Ottl J, Oberer L, Guenat C, Moss S, et al: Identification and mechanistic characterization of low-molecular-weight inhibitors for HuR. Nat Chem Biol 3: 508-515, 2007.

80. D'Agostino VG, Adami V and Provenzani A: A novel high throughput biochemical assay to evaluate the HuR protein-RNA complex formation. PLoS One 8: e72426, 2013.

81. Wu X, Lan L, Wilson DM, Marquez RT, Tsao WC, Gao P, Roy A, Turner BA, McDonald P, Tunge JA, et al: Identification and validation of novel small molecule disruptors of HuR-mRNA interaction. ACS Chem Biol 10: 1476-1484, 2015.

82. D'Agostino VP, Lal P, Mantelli B, Tiedje C, Zucal C, Thongon N, Gaestel M, Latorre E, Marinelli L, Seneci P, et al: Dihydrotanshinone-I interferes with the RNA-binding activity of HuR affecting its post-transcriptional function. Sci Rep 5: 16478, 2015.

83. Li C, Rock KL, Woda BA, Jiang Z, Fraire AE and Dresser K: IMP3 is a novel biomarker for adenocarcinoma in situ of the uterine cervix: An immunohistochemical study in comparison with p16(INK4a) expression. Mod Pathol 20: 242-247, 2007. 
84. Jiang Z, Chu PG, Woda BA, Rock KL, Liu Q, Hsieh CC, Li C, Chen W, Duan HO, McDougal S and Wu CL: Analysis of RNA-binding protein IMP3 to predict metastasis and prognosis of renal-cell carcinoma: A retrospective study. Lancet Oncol 7 : $556-564,2006$.

85. Bell JL, Wächter K, Mühleck B, Pazaitis N, Köhn M, Lederer M and Hüttelmaier S: Insulin-like growth factor 2 mRNA-binding proteins (IGF2BPs): Post-transcriptional drivers of cancer progression? Cell Mol Life Sci 70: 2657-2675, 2013.

86. Fakhraldeen SA, Clark RJ, Roopra A, Chin EN, Huang W, Castorino J, Wisinski KB, Kim T, Spiegelman VS and AlexanderCM: Two isoforms of the RNA binding protein, coding region determinant-binding protein (CRD-BP/IGF2BP1), are expressed in breast epithelium and support clonogenic growth of breast tumor cells. J Biol Chem 290: 13386-13400, 2015.

87. Gu W, Pan F and Singer RH: Blocking beta-catenin binding to the ZBP1 promoter represses ZBP1 expression, leading to increased proliferation and migration of metastatic breast-cancer cells. J Cell Sci 122: 1895-1905, 2009.

88. Gu W, Katz Z, Wu B, Park HY, Li D, Lin S, Wells AL and Singer RH: Regulation of local expression of cell adhesion and motility-related mRNAs in breast cancer cells by IMP1/ZBP1 J Cell Sci 125: 81-91, 2012.

89. Lapidus K, Wyckoff J, Mouneimne G, Lorenz M, Soon L, Condeelis JS and Singer RH: ZBP1 enhances cell polarity and reduces chemotaxis. J Cell Sci 120: 3173-3178, 2007.

90. Wang G, Huang Z, Liu X, Huang W, Chen S, Zhou Y, Li D, Singer RH and Gu W: IMP1 suppresses breast tumor growth and metastasis through the regulation of its target mRNAs Oncotarget 7: 15690-15702, 2016

91. Gu W, Wells AL, Pan F and Singer RH: Feedback regulation between zipcode binding protein 1 and beta-catenin mRNAs in breast cancer cells. Mol Cell Biol 28: 4963-4974, 2008.

92. Barghash A, Helms V and Kessler SM: Overexpression of IGF2 mRNA-binding protein 2 (IMP2/p62) as a feature of basal-like breast cancer correlates with short survival. Scand J Immunol 82: 142-143, 2015.

93. Liu W, Li Y, Wang B, Dai L, Qian W and Zhang JY: Autoimmune response to IGF2 mRNA-binding protein 2(IMP2/p62) in breast cancer. Scand J Immunol 81: 502-507, 2015.

94. McMullen ER, Gonzalez ME, Skala SL, Tran M, Thomas D, Djomehri SI, Burman B, Kidwell KM and Kleer CG: CCN6 regulates IGF2BP2 and HMGA2 signaling in metaplastic carcinomas of the breast. Breast Cancer Res Treat 172: 577-586, 2018.

95. Walter O, Prasad M, Lu S, Quinlan RM, Edmiston KL and Khan A: IMP3 is a novel biomarker for triple negative invasive mammary carcinoma associated with a more aggressive phenotype. Hum Pathol 40: 1528-1533, 2009.

96. Grimshaw MJ, Cooper L, Papazisis K, Coleman JA, Bohnenkamp HR, Chiapero-Stanke L, Taylor-Papadimitriou J and Burchell JM: Mammosphere culture of metastatic breast cancer cells enriches for tumorigenic breast cancer cells. Breast Cancer Res 10: R52, 2008.

97. Samanta S, Sharma VM, Khan A and Mercurio AM: Regulation of IMP3 by EGFR signaling and repression by ER $\beta$ : Implications for triple-negative breast cancer. Oncogene 31: 4689-4697, 2012

98. Samanta S, Sun H, Goel HL, Pursell B, Chang C, Khan A, Greiner DL, Cao S, Lim E, Shultz LD and Mercurio AM: IMP3 promotes stem-like properties in triple-negative breast cancer by regulating SLUG. Oncogene 35: 1111-1121, 2016.

99. Phillips S, Prat A, Sedic M, Proia T, Wronski A, Mazumdar S, Skibinski A, Shirley SH, Perou CM, Gill G, et al: Cell-state transitions regulated by SLUG are critical for tissue regeneration and tumor initiation. Stem Cell Rep 2: 633-647, 2014.

100. Proia TA, Keller PJ, Gupta PB, Klebba I, Jones AD, Sedic M, Gilmore H, Tung N, Naber SP, Schnitt S, et al: Genetic predisposition directs breast cancer phenotype by dictating progenitor cell fate. Cell Stem Cell 8: 149-163, 2011.

101. Samanta S, Guru S, Elaimy AL, Amante JJ, Ou J, Yu J, Zhu LJ and Mercurio AM: IMP3 stabilization of WNT5B mRNA facilitates TAZ activation in breast cancer. Cell Rep 23: 2559-2567, 2018

102. Cordenonsi M, Zanconato F, Azzolin L, Forcato M, Rosato A, Frasson C, Inui M, Montagner M, Parenti AR, Poletti A, et al The Hippo transducer TAZ confers cancer stem cell-related traits on breast cancer cells. Cell 147: 759-772, 2011.

103. Doyle L and Ross DD: Multidrug resistance mediated by the breast cancer resistance protein BCRP (ABCG2). Oncogene 22: $7340-7358,2003$
104. Hazlehurst LA, Foley NE, Gleason-Guzman MC, Hacker MP, Cress AE, Greenberger LW, De Jong MC and Dalton WS: Multiple mechanisms confer drug resistance to mitoxantrone in the human 8226 myeloma cell line. Cancer Res 59: 1021-1028, 1999.

105. Samanta S, Pursell B and Mercurio AM: IMP3 protein promotes chemoresistance in breast cancer cells by regulating breast cancer resistance protein (ABCG2) expression. J Biol Chem 288: 12569-12573, 2013

106. Kim HY, Ha Thi HT and Hong S: IMP2 and IMP3 cooperate to promote the metastasis of triple-negative breast cancer through destabilization of progesterone receptor. Cancer Lett 415: 30-39, 2018.

107. Rehfeld F, Rohde AM, Nguyen DT and Wulczyn FC: Lin28 and let-7: Ancient milestones on the road from pluripotency to neurogenesis. Cell Tissue Res 359: 145-160, 2015.

108. Shyh-Chang N and Daley GQ: Lin28: Primal regulator of growth and metabolism in stem cells. Cell Stem Cell 12: 395-406, 2013.

109. Powers JT, Tsanov KM, Pearson DS, Roels F, Spina CS, Ebright R, Seligson M, de Soysa Y, Cahan P, Theißen J, et al: Multiple mechanisms disrupt the let-7 microRNA family in neuroblastoma. Nature 535: 246-251, 2016.

110. Yao K, Qiu S, Tian L, Snider WD, Flannery JG, Schaffer DV and Chen B: Wnt regulates proliferation and neurogenic potential of Müller glial cells via a Lin28/let-7 miRNA-dependent pathway in adult mammalian retinas. Cell Rep 17: 165-178, 2016.

111. Piskounova E, Polytarchou C, Thornton JE, LaPierre RJ, Pothoulakis C, Hagan JP, Iliopoulos D and Gregory RI: Lin28A and Lin28B inhibit let-7 microRNA biogenesis by distinct mechanisms. Cell 147: 1066-1079, 2011.

112. Gibadulinova A, Bullova P, Strnad H, Pohlodek K, Jurkovicova D, Takacova M, Pastorekova S and Eliska Svastoval: CAIX-mediated control of LIN28/let-7 axis contributes to metabolic adaptation of breast cancer cells to hypoxia. Int J Mol Sci 21: 4299, 2020

113. Frost RJ and Olson EN: Control of glucose homeostasis and insulin sensitivity by the Let-7 family of microRNAs. Proc Natl Acad Sci USA 108: 21075-21080, 2011.

114. Zhu H, Shyh-Chang N, Segrè A, Shinoda G, Shah SP,Einhorn WS, Takeuchi A, Engreitz JM, Hagan JP, Kharas MG, et al: The Lin28/let-7 axis regulates glucose metabolism. Cell 147: 81-94, 2011

115. Mayr C, Hemann MT and Bartel DP: Disrupting the pairing between let-7 and Hmga2 enhances oncogenic transformation. Science 315: 1576-1579, 2007

116. Sampson VB, Rong NH, Han J, Yang Q, Aris V, Soteropoulos P, Petrelli NJ, Dunn SP and Krueger LJ: MicroRNA let-7a down-regulates MYC and reverts MYC-induced growth in Burkitt lymphoma cells. Cancer Res 67: 9762-9770, 2007.

117. Li N, Zhong X, Lin X, Guo J, Zou L, Tanyi JL, Shao Z, Liang S, Wang LP, Hwang WT, et al: Lin-28 homologue A (LIN28A) promotes cell cycle progression via regulation of cyclin-dependent kinase 2 (CDK2), cyclin D1 (CCND1), and cell division cycle 25 homolog A (CDC25A) expression in cancer. J Biol Chem 287: 17386-17397, 2012

118. Isanejad A, Alizadeh AM, Amani Shalamzari S, Khodayari H, Khodayari S, Khori V and Khojastehnjad N: MicroRNA-206, let-7a and microRNA-21 pathways involved in the anti-angiogenesis effects of the interval exercise training and hormone therapy in breast cancer. Life Sci 151: 30-40, 2016.

119. Dangi-Garimella S, Yun J, Eves EM, Newman M, Erkeland SJ, Hammond SM, Minn AJ and Rosner MR: Raf kinase inhibitory protein suppresses a metastasis signalling cascade involving LIN28 and let-7. EMBO J 28: 347-358, 2009.

120. Liu Y, Li H, Feng J, Cui X, Huang W, Li Y, Su F, Liu Q, Zhu J, Lv X, et al: Lin28 induces epithelial-to-mesenchymal transition and stemness via downregulation of let-7a in breast cancer cells. PLoS One 8: e83083, 2013

121. Wang L, Wang YX, Zhang DZ, Fang XJ, Sun PS and Xue HC: Let-7a mimic attenuates CCL18 induced breast cancer cell metastasis through Lin 28 pathway. Biomed Pharmacother 78: 301-307, 2016

122. Estrada-Bernal A, Chatterjee M, Haque SJ, Yang L, Morgan MA, Kotian S, Morrell D, Chakravarti A and Williams TM: MEK inhibitor GSK1120212-mediated radiosensitization of pancreatic cancer cells involves inhibition of DNA double-strand break repair pathways. Cell Cycle 14: 3713-3724, 2015

123. Oh JS, Kim JJ, Byun JY and Kim IA: Lin28-let7 modulates radiosensitivity of human cancer cells with activation of K-Ras. Int J Radiat Oncol Biol Phys 76: 5-8, 2010. 
124. Collis SJ, Barber LJ, Clark AJ, Martin JS, Ward JD and Boulton SJ: HCLK2 is essential for the mammalian S-phase checkpoint and impacts on Chk1 stability. Nat Cell Biol 9: 391-401, 2007.

125. Teng R, Hu Y, Zhou J, Seifer B, Chen Y, Shen J and Wang L: Overexpression of Lin28 decreases the chemosensitivity of gastric cancer cells to oxaliplatin, paclitaxel, doxorubicin, and fluorouraci in part via microRNA-107. PLoS One 10: e0143716, 2015.

126. Tian N, Han Z, Li Z, Zhou M and Fan C: Lin28/let-7/Bcl-xL pathway: The underlying mechanism of drug resistance in Hep3B cells. Oncol Rep 32: 1050-1056, 2014.

127. Lv K, Liu L, Wang L, Yu J, Liu X, Cheng Y, Dong M, Teng R, Wu L, Fu P, et al: Lin 28 mediates paclitaxel resistance by modulating p21, Rb and Let-7a miRNA in breast cancer cells. PLoS One 7: e40008, 2012

128. Okano H, Kawahara H, Toriya M, Nakao K, Shibata S and Imai T: Function of RNA-binding protein Musashi-1 in stem cells. Exp Cell Res 306: 349-356, 2005.

129. Wang XY, Penalva LQ, Yuan H, Linnoila RI, Lu J, Okano H and Glazer RI: Musashil regulates breast tumor cell proliferation and is a prognostic indicator of poor survival. Mol Cancer 9 : 221,2010

130. Shu HJ, Saito T, Watanabe H, Ito JI, Takeda H, Okano H and Kawata S: Expression of the Musashil gene encoding the RNA-binding protein in human hepatoma cell lines. Biochem Biophys Res Commun 293: 150-154, 2002.

131. Toda M, Iizuka Y, Yu W, Imai T, Ikeda E, Yoshida K, Kawase T, Kawakami Y, Okano $\mathrm{H}$ and Uyemura K: Expression of the neural RNA-binding protein Musashi1 in human gliomas. Glia 34: 1-7, 2001.

132. Battelli C, Nikopoulos GN, Mitchell JG and Verdi JM: The RNA-binding protein Musashi-1 regulates neural development through the translational repression of p21WAF-1. Mol Cell Neurosci 31: 85-96, 2006.

133. Devgan V, Mammucari C, Millar SE, Brisken C and Dotto GP p21WAF1/Cip1 is a negative transcriptional regulator of Wnt4 expression downstream of Notch1 activation. Genes Dev 19 1485-1495, 2005.

134. Wang XY, Yin Y, Yuan H, Sakamaki T, Okano H and Glazer RI: Musashil modulates mammary progenitor cell expansion through proliferin-mediated activation of the Wnt and Notch pathways. Mol Cell Biol 28: 3589-3599, 2008.

135. Glazer RI, Vo DT and Penalva LO: Musashi1: An RBP with versatile functions in normal and cancer stem cells. Front Biosci (Landmark Ed) 17: 54-64, 2012.

136. Lindsay J, Jiao X, Sakamaki T, Casimiro MC, Shirley LA, Tran TH, Ju X, Liu M, Li Z, Wang C, et al: ErbB2 induces Notch1 activity and function in breast cancer cells. Clin Trans Sci 1: 107-115, 2008.

137. Choi YM, Kim KB, Lee JH, Chun YK, An IS, An S and Bae S: $\mathrm{DBC} 2 / \mathrm{RhoBTB} 2$ functions as a tumor suppressor protein via Musashi-2 ubiquitination in breast cancer. Oncogene 36: 2802-2812, 2017.

138. Baron M: An overview of the Notch signalling pathway. Semin Cell Dev Biol 14: 113-119, 2003.

139. McGill MA and McGlade CJ: Mammalian numb proteins promote Notch1 receptor ubiquitination and degradation of the Notch1 intracellular domain. J Biol Chem 278: 23196-23203, 2003.

140. Wakamatsu Y, Maynard TM, Jones SU and Weston JA: NUMB localizes in the basal cortex of mitotic avian neuroepithelial cells and modulates neuronal differentiation by binding to NOTCH-1. Neuron 23: 71-81, 1999.

141. Reedijk M, Odorcic S, Chang L, Zhang H, Miller N, McCready DR, Lockwood G and Egan SE: High-level coexpression of JAG1 and NOTCH1 is observed in human breast cancer and is associated with poor overall survival. Cancer Res 65: 8530-8537, 2005.

142. Ayyanan A, Civenni G, Ciarloni L, Morel C, Mueller N, Lefort K, Mandinova A, Raffoul W, Fiche M, Dotto GP and Brisken C: Increased Wnt signaling triggers oncogenic conversion of human breast epithelial cells by a Notch-dependent mechanism. Proc Natl Acad Sci USA 103: 3799-3804, 2006

143. Pece S, Serresi M, Santolini E, Capra M, Hulleman E, Galimberti V, Zurrida S, Maisonneuve P, Viale G and Di Fiore PP Loss of negative regulation by Numb over Notch is relevant to human breast carcinogenesis. J Cell Biol 167: 215-221, 2004.

144. Hamaguchi M, Meth JL, von Klitzing C, Wei W, Esposito D Rodgers L, Walsh T, Welcsh P, King MC and Wigler MH: DBC2, a candidate for a tumor suppressor gene involved in breast cancer. Proc Natl Acad Sci USA 99: 13647-13652, 2002.
145. Knowles MA, Aveyard JS, Taylor CF, Harnden P and Bass S: Mutation analysis of the $8 \mathrm{p}$ candidate tumour suppressor genes DBC2 (RHOBTB2) and LZTS1 in bladder cancer. Cancer Lett 225: 121-130, 2005.

146. Freeman SN and Cress WD: RhoBTB2 (DBC2) comes of age as a multifunctional tumor suppressor. Cancer Biol Ther 10: $1123-1125,2010$

147. Wilkins A, Ping Q and Carpenter CL: RhoBTB2 is a substrate of the mammalian Cul3 ubiquitin ligase complex. Genes Dev 18: $856-861,2004$

148. Kang MH, Jeong KJ, Kim WY, Lee HJ, Gong G, Suh N, Győrffy B, Kim S, Jeong SY, Mills GB and Park YY: Musashi RNA-binding protein 2 regulates estrogen receptor 1 function in breast cancer. Oncogene 36: 1745-1752, 2017.

149. Sakakibara S, Nakamura Y, Satoh $\mathrm{H}$ and Okano H: Rna-binding protein Musashi2: developmentally regulated expression in neural precursor cells and subpopulations of neurons in mammalian CNS. J Neurosci 21: 8091-8107, 2001.

150. Troschel FM, Minte A, Ismail YM, Kamal A, Abdullah MS, Ahmed SH, Deffner M, Kemper B, Kiesel L, Eich HT, et al: Knockdown of Musashi RNA binding proteins decreases radioresistance but enhances cell motility and invasion in triple-negative breast cancer. Int J Mol Sci 21: 2169, 2020.

151. Jaggupilli A and Elkord E: Significance of CD44 and CD24 as cancer stem cell markers: An enduring ambiguity. Clin Dev Immunol 2012: 708036, 2012.

152. Fang Y, Yuan Y, Zhang LL, Lu JW, Feng JF and Hu SN: Downregulated GBX2 gene suppresses proliferation, invasion and angiogenesis of breast cancer cells through inhibiting the Wnt/ $\beta$-catenin signaling pathway. Cancer Biomark 23: 405-418, 2018.

153. Peuhu E, Virtakoivu R, Mai A, Wärri A and Ivaska J: Epithelial vimentin plays a functional role in mammary gland development. Development 144: 4103-4113, 2017.

154. Chen D, Sun Y, Wei Y, Zhang P, Rezaeian AH, Teruya-Feldstein J, Gupta S, Liang H, Lin HK, Hung MC and Ma L: LIFR is a breast cancer metastasis suppressor upstream of the Hippo-YAP pathway and a prognostic marker. Nat Med 18: 1511-1517, 2012.

155. Yan W, Zhang J, Zhang Y, Jung YS and Chen X: p73 expression is regulated by RNPC1, a target of the p53 family, via mRNA stability. Mol Cell Biol 32: 2336-2348, 2012.

156. Xue JQ, Xia TS, Liang XQ, Zhou W, Cheng L, Shi L, Wang Y and Ding Q: RNA-binding protein RNPC1: Acting as a tumor suppressor in breast cancer. BMC Cancer 14: 322, 2014.

157. Feldstein O, Ben-Hamo R, Bashari D, Efroni S and Ginsberg D RBM38 is a direct transcriptional target of E2F1 that limits E2F1-induced proliferation. Mol Cancer Res 10: 1169-1177, 2012.

158. Zheng L, Zhang Z, Zhang S, Guo Q, Zhang F, Gao L, Ni H, Guo X, Xiang C and Xi T: RNA binding protein RNPC1 inhibits breast cancer cell metastasis via activating STARD13-correlated ceRNA network. Mol Pharm 15: 2123-2132, 2018.

159. Shu L, Yan W and Chen X: RNPC1, an RNA-binding protein and a target of the p53 family, is required for maintaining the stability of the basal and stress-induced p21 transcript. Genes Dev 20: 2961-2972, 2006.

160. Li XX, Shi L, Zhou XJ, Wu J, Xia TS, Zhou WB, Sun X, Zhu L, Wei JF and Ding Q: The role of c-Myc-RBM38 loop in the growth suppression in breast cancer. J Exp Clin Canc Res 36: 49, 2017.

161. Dang CV: MYC on the path to cancer. Cell 149: 22-35, 2012

162. Shi L, Xia TS, Wei XL, Zhou W, Xue J, Cheng L, Lou P, Li C, Wang Y, Wei JF and Ding Q: Estrogen receptor (ER) was regulated by RNPC1 stabilizing mRNA in ER positive breast cancer. Oncotarget 6: 12264-12278, 2015.

163. Lou P, Li C, Shi L, Xia TS, Zhou W, Wu J, Zhou X, Li X, Wang Y, Wei JF and Ding Q: RNPC1 enhances progesterone receptor functions by regulating its mRNA stability in breast cancer. Oncotarget 8: 16387-16400, 2017.

164. Di Cristofano A and Pandolfi PP: The multiple roles of PTEN in tumor suppression. Cell 100: 387-390, 2000.

165. Maehama T and Dixon JE: The tumor suppressor, PTEN/MMAC1, dephosphorylates the lipid second messenger, phosphatidylinositol 3,4,5-trisphosphate. J Biol Chem 273: 13375-13378, 1998

166. Yamada KM and Araki M: Tumor suppressor PTEN: Modulator of cell signaling, growth, migration and apoptosis. J Cell Sci 114 2375-2382, 2001

167. Chow LM and Baker SJ: PTEN function in normal and neoplastic growth. Cancer Lett 241: 184-196, 2006. 
168. Zhou XJ, Wu J, Shi L, Li XX, Zhu L, Sun X, Qian JY, Wang Y, Wei JF and Ding Q: PTEN expression is upregulated by a RNA-binding protein RBM38 via enhancing its mRNA stability in breast cancer. J Exp Clin Cancer Res 36: 149, 2017.

169. Aparicio LA, Abella V, Valladares M and Figueroa A Posttranscriptional regulation by RNA-binding proteins during epithelial-to-mesenchymal transition. Cell Mol Life Sci 70: 4463-4477, 2013.

170. Wu J, Zhou XJ, Sun X, Xia TS, Li XX, Shi L, Zhu L, Zhou WB, Wei JF and Ding Q: RBM38 is involved in TGF- $\beta$-induced epithelial-to-mesenchymal transition by stabilising zonula occludens-1 mRNA in breast cancer. Br J Cancer 117: 675-684, 2017.

171. Cho SJ, Jung YS, Zhang J and Chen X: The RNA-binding protein RNPC1 stabilizes the mRNA encoding the RNA-binding protein $\mathrm{HuR}$ and cooperates with $\mathrm{HuR}$ to suppress cell proliferation. J Biol Chem 287: 14535-14544, 2012.

172. Lin Q, Taylor SJ and Shalloway D: Specificity and determinants of Sam68 RNA binding. Implications for the biological function of K homology domains. J Biol Chem 272: 27274-27280, 1997.

173. Chen T, Damaj BB, Herrera C, Lasko P and Richard S Self-association of the single-KH-domain family members Sam68, GRP33, GLD-1, and Qk1: Role of the KH domain. Mol Cell Biol 17: 5707-5718, 1997.

174. Paronetto MP, Cappellari M, Busà R, Pedrotti S, Vitali R, Comstock C, Hyslop T, Knudsen KE and Sette C: Alternative splicing of the cyclin D1 proto-oncogene is regulated by the RNA-binding protein Sam68. Cancer Res 70: 229-239, 2010.

175. Chawla G, Lin CH, Han A, Shiue L, Ares M Jr and Black DL: Sam68 regulates a set of alternatively spliced exons during neurogenesis. Mol Cell Biol 29: 201-213, 2009.

176. Derry JJ, Richard S, Valderrama Carvajal H, Ye X, Vasioukhin V, Cochrane AW, Chen T and Tyner AL: Sik (BRK) phosphorylates Sam68 in the nucleus and negatively regulates its RNA binding ability. Mol Cell Biol 20: 6114-6126, 2000.

177. Aubele M, Walch AK, Ludyga N, Braselmann H, Atkinson MJ Luber B, Auer G, Tapio S, Cooke T and Bartlett JM: Prognostic value of protein tyrosine kinase 6 (PTK6) for long-term survival of breast cancer patients. Br J Cancer 99: 1089-1095, 2008

178. Espejo A, Côté J, Bednarek A, Richard S and Bedford M: A protein-domain microarray identifies novel protein-protein interactions. Biochem J 367: 697-702, 2002.

179. Weng Z, Thomas SM, Rickles RJ, Taylor JA, Brauer AW, Seidel-Dugan C, Michael WM, Dreyfuss G and Brugge JS Identification of Src, Fyn, and Lyn SH3-binding proteins: Implications for a function of SH3 domains. Mol Cell Biol 14 4509-4521, 1994.

180. Richard S, Yu D, Blumer KJ, Hausladen D, Olszowy MW, Connelly PA and Shaw AS: Association of p62, a multifunctional SH2- and SH3-domain-binding protein, with src family tyrosine kinases, Grb2, and phospholipase C gamma-1. Mol Cell Biol 15: 186-197, 1995 .

181. Taylor SJ, Anafi M, Pawson T and Shalloway D: Functional interaction between c-Src and its mitotic target, Sam 68. J Biol Chem 270: 10120-10124, 1995.

182. Taylor SJ and Shalloway D: An RNA-binding protein associated with Src through its $\mathrm{SH} 2$ and $\mathrm{SH} 3$ domains in mitosis. Nature 368: 867-871, 1994.

183. Fumagalli S, Totty NF, Hsuan JJ and Courtneidge SA: A target for Src in mitosis. Nature 368: 871-874, 1994.

184. Paronetto MP, Venables JP, Elliott DJ, Geremia R, Rossi P and Sette C: Tr-kit promotes the formation of a multimolecular complex composed by Fyn, PLCgamma1 and Sam68. Oncogene 22: 8707-8715, 2003.
185. Paronetto MP, Achsel T, Massiello A, Chalfant CE and Sette C: The RNA-binding protein Sam68 modulates the alternative splicing of Bcl-x. J Cell Biol 176: 929-939, 2007.

186. Côté J, Boisvert FM, Boulanger MC, Bedford MT and Richard S: Sam68 RNA binding protein is an in vivo substrate for protein arginine N-methyltransferase 1. Mol Biol Cell 14: 274-287, 2003.

187. Bedford MT, Frankel A, Yaffe MB, Clarke S, Leder P and Richard S: Arginine methylation inhibits the binding of proline-rich ligands to Src homology 3 , but not WW, domains. J Biol Chem 275: 16030-16036, 2000.

188. Babic I, Jakymiw A and Fujita DJ: The RNA binding protein Sam68 is acetylated in tumor cell lines, and its acetylation correlates with enhanced RNA binding activity. Oncogene 23 3781-3789, 2004.

189. Babic I, Cherry E and Fujita DJ: SUMO modification of Sam68 enhances its ability to repress cyclin D1 expression and inhibits its ability to induce apoptosis. Oncogene 25: 4955-4964, 2006.

190. Barker KT, Jackson LE and Crompton MR: BRK tyrosine kinase expression in a high proportion of human breast carcinomas. Oncogene 15: 799-805, 1997.

191. Ostrander JH, Daniel AR and Lange CA: Brk/PTK6 signaling in normal and cancer cell models. Curr Opin Pharmacol 10: 662-669, 2010

192. Lukong KE, Larocque D, Tyner AL and Richard S: Tyrosine phosphorylation of sam 68 by breast tumor kinase regulates intranuclear localization and cell cycle progression. J Biol Chem 280: 38639-38647, 2005.

193. Lukong KE and Richard S: Sam68, the KH domain-containing superSTAR. Biochim Biophys Acta 1653: 73-86, 2003.

194. Song L, Wang L, Li Y, Xiong H, Wu J, Li J and Li M: Sam68 up-regulation correlates with, and its down-regulation inhibits, proliferation and tumourigenicity of breast cancer cells. J Pathol 222: 227-237, 2010.

195. Huot ME, Brown CM, Lamarche-Vane N and Richard S: An adaptor role for cytoplasmic Sam68 in modulating Src activity during cell polarization. Mol Cell Biol 29: 1933-1943, 2009.

196. Wang Y, Zhang W, Wang X, Wang D, Xie J, Tang C, Xi Q, Zhong J and Deng Y: Expression of Sam68 correlates with cell proliferation and survival in epithelial ovarian cancer. Reprod Sci 24: 97-108, 2017.

197. Xiao J, Wang Q, Yang Q, Wang H, Qiang F, He S, Cai J, Yang L and Wang Y: Clinical significance and effect of Sam68 expression in gastric cancer. Oncol Lett 15: 4745-4752, 2018.

198. Fu K, Sun X, Xia X, Hobbs RP, Guo Y, Coulombe PA and Wan F: Sam68 is required for the growth and survival of nonmelanoma skin cancer. Cancer Med 8: 6106-6113, 2019.

199. Huot MÉ, Vogel G, Zabarauskas A, Ngo CT, CoulombeHuntington J, Majewski J and Richard S: The Sam68 STAR RNA-binding protein regulates mTOR alternative splicing during adipogenesis. Mol Cell 46: 187-199, 2012.

200. Paez J and Sellers WR: PI3K/PTEN/AKT pathway. A critical mediator of oncogenic signaling. Cancer Treat Res 115: 145-167, 2003.

201. Richard S, Vogel G, Huot ME Guo T, Muller WJ and Lukong KE: Sam68 haploinsufficiency delays onset of mammary tumorigenesis and metastasis. Oncogene 27: 548-556, 2008

202. Richard S, Torabi N, Franco GV, Tremblay GA, Chen T, Vogel G, Morel M, Cléroux P, Forget-Richard A, Komarova S, et al: Ablation of the Sam68 RNA binding protein protects mice from age-related bone loss. PLoS Genet 1: e74, 2005.

This work is licensed under a Creative Commons Attribution-NonCommercial-NoDerivatives 4.0 International (CC BY-NC-ND 4.0) License. 